\title{
Performance of wear resistant MCrAlY coatings with oxide dispersion strengthening
}

Giovanni Bolelli ${ }^{\mathrm{a}}$, Christoph Vorkötter ${ }^{\mathrm{b}}$, Luca Lusvarghi ${ }^{\mathrm{a}}$, Stefania Morelli ${ }^{\mathrm{a}}$, Veronica Testa ${ }^{\mathrm{a}}$, Robert Vaßen ${ }^{b}$

a Dipartimento di Ingegneria “Enzo Ferrari”, University of Modena and Reggio Emilia, Via P. Vivarelli 10/1, 41125 Modena (MO), Italy

${ }^{b}$ Forschungszentrum Jülich GmbH, Institute of Energy and Climate Research, IEK- 1, Wilhelm Johnen-Straße, 52425 Jülich, Germany

\begin{abstract}
Aiming to devise suitable materials for sliding wear protection at high temperature, aluminium oxide-dispersion strengthened (ODS) CoNiCrAlY coatings were manufactured by vacuum plasma spraying (VPS). Feedstock materials were ball-milled powders with 2, 10 and 30 wt.\% $\mathrm{Al}_{2} \mathrm{O}_{3}$ content. The ball-on-disc sliding wear behaviour of the coatings was tested at $750{ }^{\circ} \mathrm{C}$ against an $\mathrm{Al}_{2} \mathrm{O}_{3}$ counterpart, and compared to a pure CoNiCrAlY coating (obtained from a commercial feedstock not subjected to ball milling) and to an uncoated Ni-base superalloy. Sliding wear rates decrease from the uncoated superalloy $\left(\approx 3 \times 10^{-5} \mathrm{~mm}^{3} /(\mathrm{N} \cdot \mathrm{m})\right)$ to the pure CoNiCrAlY coating $\left(\approx 2 \times 10^{-5} \mathrm{~mm}^{3} /(\mathrm{N} \cdot \mathrm{m})\right)$ and to the ODS ones, with the notable exception of the 10 wt. $\% \mathrm{Al}_{2} \mathrm{O}_{3}$-containing sample.

Analyses of worn samples indicate that pure CoNiCrAlY is subject to severe adhesive wear, mitigated by the formation of a thick $(>1 \mu \mathrm{m})$ "glaze" layer via compaction and (probable) sintering of tribo-oxidized debris particles. Addition of $\mathrm{Al}_{2} \mathrm{O}_{3}$ particles to the CoNiCrAlY matrix can either enhance or worsen the "glaze" stability. Specifically, a coating strengthened with 30
\end{abstract}


wt. $\% \mathrm{Al}_{2} \mathrm{O}_{3}$ provides an especially good mechanical support to the "glaze". This produces beneficial effects resulting in a particularly low wear rate of $\approx 3 \times 10^{-6} \mathrm{~mm}^{3} /(\mathrm{N} \cdot \mathrm{m})$.

Key-words: Thermal spray coatings; Cermets; Sliding wear; High temperature. 


\section{Introduction}

Gas turbine components need to resist high thermal and mechanical loads due to fuel combustion at high temperatures. Engine parts made of superalloys offer a wide range of service temperature and load capabilities [1]. However, in areas such as the combustion chamber or first-stage blades and vanes, gas temperatures are well above the service limits of Ni-based superalloys (i.e. $>1000$ $\left.{ }^{\circ} \mathrm{C}\right)$ [2]. In order to enable the use of superalloys even beyond the service temperature limits, parts are coated by thermally sprayed thermal barriers to protect them against high temperatures and oxidation $[3,4]$. To merge the ceramic top coat of a thermal barrier system with the substrate, an interconnecting bond coat layer is necessary: it enhances the adhesion of the ceramic top coat and provides oxidation protection to the substrate material. MCrAlYs, where $\mathrm{M}$ stands for Co or $\mathrm{Ni}$, are the state of the art thermally-sprayed bond-coat materials used in turbine engine applications $[3,4]$.

In sections of the gas turbine where the thermal loads are lower, the ceramic top coat layer can be saved [5]. For instance, blades and vanes in later stages of a gas turbine or in the compressor face gases at lower temperatures (e.g. $\left.750{ }^{\circ} \mathrm{C}\right)$, so for these blades or vanes, wear resistant and oxidation resistant coatings are commonly used. Wear resistance is especially important at blade tips, which run into an abradable layer on the inner turbine shroud for perfect sealing. Wear of the tip can result from hard ceramic phases contained in the abradable layer, and/or from foreign objects being trapped between the tip and shroud. These might be e.g. sand particles running through the gas turbine or fractured parts of failed TBCs [6].

Other parts requiring wear protection at high temperature in a gas turbine include oil-free journal bearings, which operate above $500{ }^{\circ} \mathrm{C}$ [7]. Further examples of gas turbine components experiencing high-temperature sliding contacts are listed in [8]. Among the protective coatings proposed for such applications are those obtained by plasma spray processing of patented powder 
blends with $\mathrm{NiCr}$ or NiMoAl matrices, $\mathrm{Cr}_{2} \mathrm{O}_{3}$ hard phase and solid lubricants (metallic silver and fluorides) $[7,8]$. Those coatings, known as PS304 and PS400, exhibited good performance in labscale tests as well as in test rigs, but also some limits especially at temperatures above $\approx 750{ }^{\circ} \mathrm{C}$. Other promising coating candidates for the protection of gas turbine parts exposed to wear are aluminium oxide-dispersion strengthened (ODS) MCrAlYs due to their enhanced oxidation resistance [9-12] and erosion resistance [13]. In previous publications, some of the present authors have already explored the high-temperature sliding wear behaviour of NiCrAlY alloy coatings strengthened with fine $\mathrm{Al}_{2} \mathrm{O}_{3}$ [14] or $\mathrm{Al}_{2} \mathrm{O}_{3}$ + hexagonal boron nitride (h-BN) [15]. The coatings were obtained by a "hybrid" plasma spraying process, whereby the torch was simultaneously fed with a dry NiCrAlY powder and water-based suspensions of sub-micrometric $\mathrm{Al}_{2} \mathrm{O}_{3}$ and h-BN particles. Sliding wear losses in ball-on-disc tests at $700{ }^{\circ} \mathrm{C}$ approached the values obtained with high Velocity Oxygen-Fuel (HVOF) sprayed $\mathrm{Cr}_{3} \mathrm{C}_{2}-\mathrm{NiCr}$. Since the NiCrAlY matrix also has advantages over $\mathrm{Cr}_{3} \mathrm{C}_{2}-\mathrm{NiCr}$ in terms of better oxidation and hot corrosion resistance, these coatings are particularly promising, but also reveal some drawbacks. Separate feeding the NiCrAlY matrix and the ceramic reinforcement allows for flexibility and lower costs, but bonding strength between these phases is limited. Manufacturing an ODS material is more expensive because of additional powder processing steps, but reinforcing phases are finer, more firmly embedded and uniformly dispersed in the matrix. It should also be possible to add more reinforcing phase than the maximum content of $\approx 18 \mathrm{wt} . \%$ attained in [15]. The amount of hard phase can also be higher and its distribution more homogeneous than it can be achieved with blends, such as it was done in [7,8]. At the same time, using an MCrAlY matrix should overcome any dimensional stability issues even at the highest temperatures. In this study, the sliding wear resistance of plasma sprayed ODS CoNiCrAlY coatings containing up to $30 \mathrm{wt} . \%$ reinforcing alumina phase is therefore studied at high temperature. 


\section{Experimental procedures}

\subsection{Samples' manufacturing}

Four different coatings with similar thickness were applied to single crystal superalloy discs with $30 \mathrm{~mm}$ diameter by vacuum plasma spraying. The standard material, hereafter referred to as "Non-ODS" material or "0 wt.\% alumina addition", was a commercial Co-based bond coat material (Amdry 9954, Oerlikon Metco, Wohlen, Switzerland: nominal composition Co-32Ni21Cr-8Al-0.5Y, wt.\%).

Three different aluminium oxide dispersion strengthened powders, hereafter named "X \%-ODS" according to the alumina concentration ranging from 2 to $30 \mathrm{wt} . \%$, were obtained using Amdry 995 powders with the same Co-32Ni-21 Cr-8Al-0.5Y composition and alumina powder (Martoxid MR70, Martinswerk, Bergheim, Germany). The ODS powders were produced in several milling runs performed with a high energy milling facility (Attritor Simoloyer CM01, ZoZ GmbH, Wenden, Germany) with a one litre steel milling chamber, $5 \mathrm{~mm}$ diameter steel milling balls and a powder to milling ball ratio of 1:10. Each milling run contained a $120 \mathrm{~g}$ mixture of the mentioned CoNiCrAlY and alumina powders and, on demand, an additional process control agent (stearic acid). The powder mixture was set to $2 \mathrm{wt.} \%, 10 \mathrm{wt} . \%$ or $30 \mathrm{wt} . \%$ alumina addition: chemical compositions are presented in Table 1. Chemical composition was measured by inductive coupled plasma optical emission spectroscopy and combustion analysis. Size distributions (Table 1) were determined by laser diffraction with a Horiba LA-950 V2 analyser (Horiba Ltd, Kyoto, Japan).

A milling procedure took 4-6 h with a variation in milling speed. One milling speed cycle was $1 \mathrm{~min}$ at $500 \mathrm{rpm}$ and $4 \mathrm{~min}$ at $870 \mathrm{rpm}$. In order to compensate the different powder properties, milling parameters were slightly varied. Thus, in case of $2 \mathrm{wt} . \%$ alumina powder mixture, 0.5 wt.\% stearic acid was added to the powder mixture as process control agent in order to limit cold 
welding (e.g. on the milling chamber wall) during milling (6 h). Cycling the milling speed and stearic acid addition enabled achieving well embedded alumina in the base material $[11,12]$. For 10 wt. $\%$ and 30 wt.\% alumina content, stearic acid addition was not necessary and the milling time could be reduced to $4 \mathrm{~h}$. The $30 \mathrm{wt}$. \% ODS material was milled at higher milling/mixing speed $(1600 / 800 \mathrm{rpm})$ to ensure proper embedding of alumina. All milling parameters are summarized in Table 2. The pure CoNiCrAlY material (Non-ODS) has no alumina addition and was not subjected to ball milling. To reach suitable powder quality for thermal spray, milled powders were sieved to 20-56 $\mu \mathrm{m}$. To obtain a sufficiently large amount of ODS powder for thermal spraying purposes, the sieved $30 \mathrm{wt} . \%$ ODS powder batch was enlarged by some ODS powder with the same composition and microstructure, but slightly different milling production parameters.

Table 1. Chemical compositions in weight percent for substrate material ERBO-1 (CMSX-4), base material Amdry995 and the ODS powders; size distributions are also provided [11].

\begin{tabular}{|l|l|l|l|l|l|l|l|l|l|l|l|l|l|l|l|l|}
\hline Material & $\mathrm{Ni}$ & $\mathrm{Co}$ & $\mathrm{Cr}$ & $\mathrm{W}$ & $\mathrm{Re}$ & $\mathrm{Mo}$ & $\mathrm{Al}$ & $\mathrm{Ti}$ & $\mathrm{Ta}$ & $\mathrm{Fe}$ & $\mathrm{C}$ & $\mathrm{Y}$ & $\mathrm{O}$ & $\begin{array}{l}\mathrm{D}_{10} \\
{[\mu \mathrm{m}]}\end{array}$ & $\begin{array}{l}\mathrm{D}_{50} \\
{[\mu \mathrm{m}]}\end{array}$ & $\begin{array}{l}\mathrm{D}_{90} \\
{[\mu \mathrm{m}]}\end{array}$ \\
\hline ERBO1 & $\mathrm{Bal}$ & 9 & 6.5 & 6 & 3 & 0.6 & 5.6 & 1 & 6.5 & - & 0.01 & & - & - & - & - \\
\hline $\begin{array}{l}\text { Amdry } \\
995\end{array}$ & 34 & $\mathrm{Bal}$ & 21.3 & - & - & - & 8.39 & - & - & - & - & 0.42 & - & 21 & 32 & 49 \\
\hline $2 \%$ & 31.5 & 37.7 & 20.8 & 0.04 & - & - & 8.7 & - & 0.01 & 0.28 & 0.32 & 0.46 & 1.13 & 21 & 34 & 52 \\
\hline $\begin{array}{l}10 \% \\
\text { ODS }\end{array}$ & 29.8 & 35.6 & 19.7 & 0.02 & - & - & 12.7 & - & 0.01 & 0.12 & 0.03 & 0.42 & 4.62 & 25 & 37 & 53 \\
\hline $30 \%$ & 22.4 & 27.2 & 14.9 & 0.07 & - & - & 20.1 & - & 0.02 & 1.56 & 0.05 & 0.28 & 13.04 & 12 & 29 & 49 \\
\hline
\end{tabular}


Table 2. Oxide dispersion strengthened powders' milling parameters for producing $120 \mathrm{~g}$ powder mixture per milling run.

\begin{tabular}{|c|c|c|c|c|}
\hline $\begin{array}{l}\text { Alumina } \\
\text { content } \\
\text { [wt. \%] }\end{array}$ & $\begin{array}{l}\text { Process } \\
\text { control } \\
\text { agent }\end{array}$ & $\begin{array}{l}\text { Milling speed } \\
(4 \mathrm{~min} / \text { cycle }) \\
{[\mathrm{rpm}]}\end{array}$ & $\begin{array}{l}\text { Mixing } \\
\text { speed } \\
(1 \mathrm{~min} / \text { cycle }) \\
{[\mathrm{rpm}]}\end{array}$ & $\begin{array}{l}\text { Total } \\
\text { milling/mixing } \\
\text { time } \\
{[\mathrm{h}]}\end{array}$ \\
\hline $2 \%$ & $0.5 \mathrm{wt} . \%$ & 870 & 500 & 6 \\
\hline $10 \%$ & - & 870 & 500 & 4 \\
\hline $30 \%$ & - & 1600 & 800 & 4 \\
\hline NonODS & - & no milling & - & - \\
\hline
\end{tabular}

Table 3. Process parameters for vacuum plasma spray.

\begin{tabular}{|c|c|c|c|c|c|c|c|c|c|}
\hline System & $\begin{array}{l}\text { Plasma } \\
\text { Torch }\end{array}$ & $\begin{array}{l}\text { Current } \\
{[\mathrm{A}]}\end{array}$ & $\begin{array}{l}\text { Voltage } \\
{[\mathrm{V}]}\end{array}$ & $\begin{array}{l}\mathrm{Ar} / \mathrm{H}_{2} \\
\text { flow } \\
\text { rates } \\
\text { [slpm] }\end{array}$ & $\begin{array}{l}\text { Feeding } \\
\text { Gas (Ar) } \\
\text { flow rate } \\
\text { [slpm] }\end{array}$ & $\begin{array}{l}\text { Powder } \\
\text { feed } \\
\text { rate } \\
{[\mathrm{g} / \mathrm{min}]}\end{array}$ & $\begin{array}{l}\text { Chamber } \\
\text { pressure }\end{array}$ & $\begin{array}{l}\text { Spray } \\
\text { distance } \\
{[\mathrm{mm}]}\end{array}$ & $\begin{array}{l}\text { Robot } \\
\text { speed } \\
{[\mathrm{mm} / \mathrm{s}]}\end{array}$ \\
\hline $\begin{array}{l}\text { Vacuum } \\
\text { plasma } \\
\text { spraying }\end{array}$ & F4 & $\begin{array}{l}640 \\
\text { (Non-ODS) } \\
/ 680 \text { (ODS) }\end{array}$ & 70 & $50 / 9$ & 1.7 & $60-49$ & 60 mbar & 275 & 440 \\
\hline
\end{tabular}

All coatings were sprayed on substrates made of Ni-based single crystal turbine blade material ERBO 1 (chemical composition similar to CMSX-4: see Table 1), which was cast by the service project Z01 of the SFB Transregio 103 allocated at Friedrich-Alexander University Erlangen Nürnberg. Spark erosion was used to cut the substrate into discs with $30 \mathrm{~mm}$ diameter and thicknesses from 5 to $8 \mathrm{~mm}$. Substrate discs were cleaned by grit blasting (F36 silicon oxide) resulting in a constant roughness $\mathrm{R}_{\mathrm{a}}=2.73 \pm 0.22 \mu \mathrm{m}$, measured by a CT350 profilometer with a CHR100 confocal white light sensor (CyberTECHNOLOGIES GmbH, Ingolstadt, Germany). Coatings with a thickness of $360 \mu \mathrm{m}$ to $440 \mu \mathrm{m}$ (measured by a micrometre screw) were sprayed 
by vacuum plasma spraying using an F4 gun (Oerlikon Metco, Wohlen, Switzerland). Detailed spraying parameters are presented in Table 3 . The volumetric powder feeder was set at $15 \%$ of its maximum rotation speed. Powder feed rate varies due to the different densities of the feedstock powders.

Roughness values of the as-sprayed ODS coatings were presented in previous studies [11].

\subsection{Microstructure and materials characterization}

Grit blasted steel samples $(35 \times 40 \times 10 \mathrm{~mm})$ were coated in the same spray run as the single-crystal superalloy disks. Embedded cross sections of the steel samples were ground to P4000 SiC paper and polished with diamond suspensions $(3 \mu \mathrm{m}, 1 \mu \mathrm{m}, 50 \mathrm{~nm})$. For microstructure analysis a scanning electron microscope (SEM: Phenom, Phenomworld B.V., Eindhoven, The Netherlands) was used. Coating thicknesses were measured by the AnalySIS software (Olympus Soft imaging solutions $\mathrm{GmbH}$ ) with 20 measurement points per sample on a total of 10 images. The errors correspond to the standard deviation of the mean thickness values for each image.

Hardness measurements were done by a DuraminA300 (Struers GmbH, Willich, Germany), where the hardness values were extracted by optical measurement of the indent dimensions. Indents were performed with a $500 \mathrm{gf}$ load on $1 \mathrm{~mm}$-thick, $2 \mathrm{~mm}$-wide, $1 \mu \mathrm{m}$-polished surfaces. For all measurements, the results of 10 indents were averaged and the errors correspond to the standard deviation of these hardness values.

\subsection{High temperature wear testing}

The sliding wear resistance of the ODS samples deposited onto the ERBO-1 single-crystal superalloy discs was characterized by ball-on-disc testing (High Temperature Tribometer, Anton Paar TriTec, Peseux, Switzerland) under unidirectional rotation configuration, at a temperature of 
$750{ }^{\circ} \mathrm{C}$ in air. These conditions mimic the service conditions typical of a high-temperature sliding process, and the temperature approaches the operational limit of the CoNiCrAlY matrix according to the manufacturer's specifications [16]. Counterparts were $\mathrm{Al}_{2} \mathrm{O}_{3}$ spheres of $6 \mathrm{~mm}$ diameter. Tested surfaces were ground with SiC papers (from 320 mesh to 2500 mesh) and polished with $3 \mu \mathrm{m}$ polycrystalline diamond suspension, down to a final roughness $\mathrm{R}_{\mathrm{a}}<0.1 \mu \mathrm{m}$. $\mathrm{Al}_{2} \mathrm{O}_{3}$ retains high hot hardness; therefore, as previously stated in [14], its usage approaches a service condition that involves contact with a hard counterpart (e.g. a ceramic or ceramic-coated surface) or a hard phase-containing counterpart. This is pertinent to both blade tips sliding against abradable seals, and foil bearings, as listed in the Introduction. Although dedicated test rigs exist to simulate the specific operating conditions in each of these applications $[8,17]$, a simpler, labscale test can be preferable for a preliminary assessment of the viability of the proposed ODS coatings. $\mathrm{Al}_{2} \mathrm{O}_{3}$ is also chemically inert; therefore, it does not introduce additional tribochemical interactions, which would complicate the interpretation of the results and reduce the generality of the findings. Test conditions also include $5 \mathrm{~N}$ normal load, $0.20 \mathrm{~m} / \mathrm{s}$ relative sliding speed, $2500 \mathrm{~m}$ sliding distance, $9 \mathrm{~mm}$ wear track radius. These conditions ensure comparability with the published results of other high-temperature sliding wear tests performed by the authors on metallic and composite coating systems, including similar $\mathrm{MCrAlY}+\mathrm{Al}_{2} \mathrm{O}_{3}$ composites obtained by "hybrid" plasma spraying $[14,15,18,19]$. The system was inductively heated from the base plate and sample temperature was monitored with a thermocouple in contact with its rear face. Heating lasted $1 \mathrm{~h}$ and the system was then left in isothermal conditions for $40 \mathrm{~min}$ before the test commenced, in order to ensure temperature homogeneity.

Two specimens were tested for each sample type. The friction coefficient was recorded during the test by measuring the tangential force with a load cell attached to the ball holder. The wear volume loss of the samples was measured using a non-contact, structured-light profilometer 
(ConfoCam, Confovis GmbH, Jena, Germany) attached to an optical microscope (Nikon Eclipse LV150N) operated with a $20 \times$ objective. The volume loss of the counterpart was assessed by measuring the diameter of the circular wear track left on the ball and calculating the volume of the corresponding spherical cap. All volume loss data was converted to dimensional wear coefficient $K$ according to the relation $K=V /(P \cdot s)$, where $V=$ volume loss, $P=$ normal load, $s=$ relative sliding distance.

Top surfaces and cross-sections of the wear tracks were inspected by scanning electron microscopy (SEM: Nova NanoSEM 450, FEI - ThermoFisher Scientific) and energy-dispersive X-ray (EDX) spectroscopy (Quantax-200, Bruker). In order to prevent artificial pull-out damage of surface tribofilms, cross-sections were prepared by cold-mounting the worn samples in epoxy resin before metallographic cutting and grinding/polishing with $\mathrm{SiC}$ papers (up to $2500 \mathrm{mesh}$ ), $3 \mu \mathrm{m}$ polycrystalline diamond paste and colloidal silica. The phase composition of oxide layers and tribo-layers developed outside and inside the wear tracks was investigated by micro-Raman spectroscopy (LabRam spectrometer, Horiba Jobin-Yvon, Longjumeau, France) using a 532 nmwavelength laser focused through a $100 \times$ objective. The phase evolution of the coatings after exposure to high temperatures was assessed by X-ray diffraction (XRD: X'Pert PRO, PANAlytical, Almelo, The Netherlands) outside the wear track, using $\mathrm{Cu}-\mathrm{K} \alpha$ radiation emitted from a source operated at $40 \mathrm{kV}, 40 \mathrm{~mA}$ and detected with a $1 \mathrm{D}$ array of solid-state detectors (X'Celerator, PANAlytical). The microhardness of the coatings after high-temperature wear testing was measured on the polished cross-sections using a Vickers indenter (Micro-Combi Tester, Anton-Paar) under a $5 \mathrm{~N}(\approx 500 \mathrm{gf})$ load (at least 15 indents per sample). 


\section{Results and discussion}

\subsection{Structure and microstructure of as-deposited coatings}

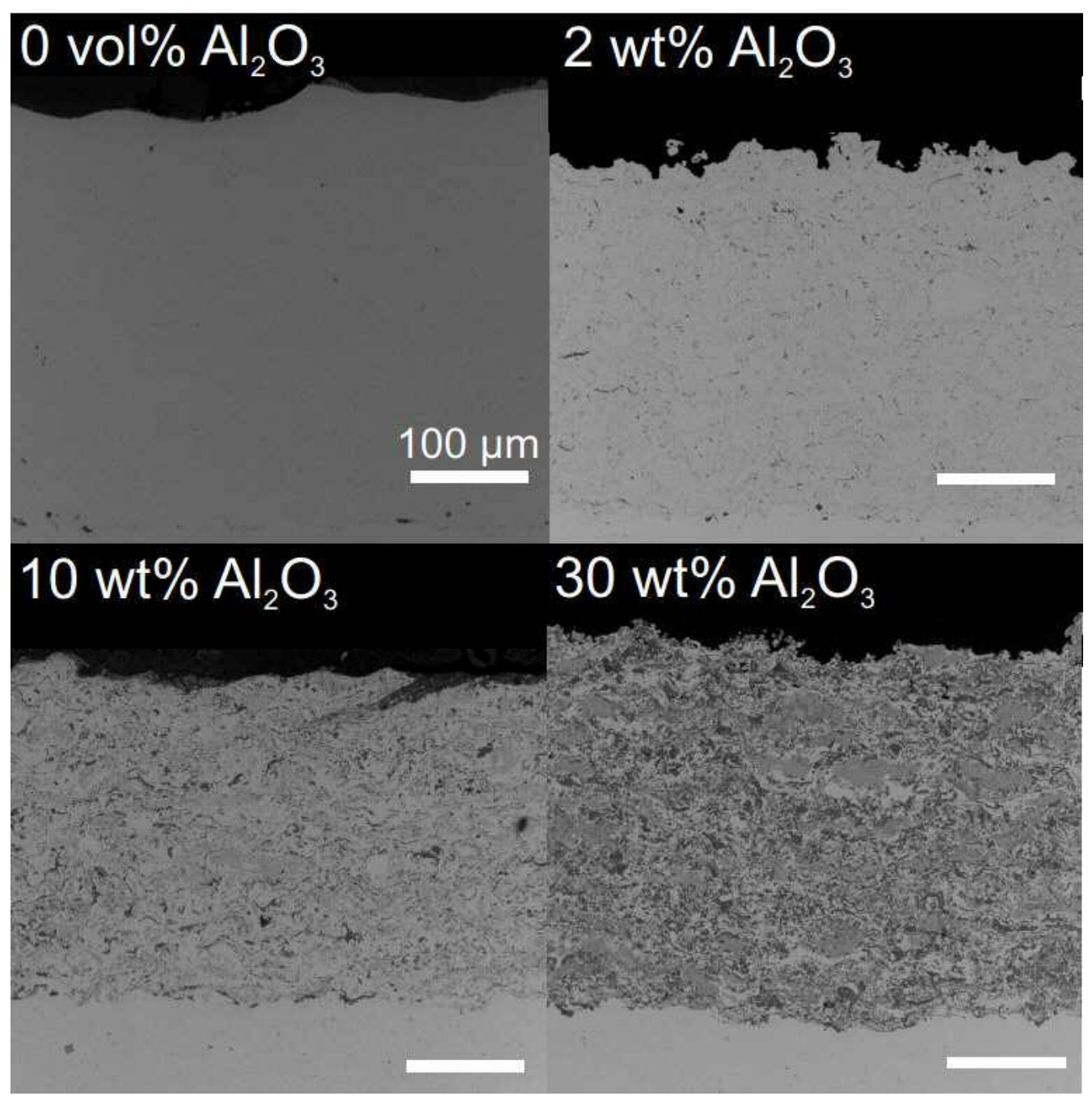

Figure 1. Cross sections of vacuum plasma sprayed oxide dispersion strengthened coatings with different alumina contents on steel substrates.

Cross sections of the untreated "as-sprayed" coatings show a homogeneous alumina distribution and a good link between the coating and the substrate (Figure 1). Coatings are thick to minimize the influence of the substrate material on the wear test. Thicknesses range from $344 \mu \mathrm{m}$ to $257 \mu \mathrm{m}$ (Table 4). The roughness of the coatings is in the $\mathrm{R}_{\mathrm{a}} \approx 8-9 \mu \mathrm{m}$ range: roughness 
variation might occur through the different particle size distributions of the ODS powders (Table 1) $[11]$.

Table 4. Coating and substrate thicknesses [ $\mu \mathrm{m}]$.

\begin{tabular}{|l|l|l|l|l|l|}
\hline Sample & Non-ODS & ODS 2\% & ODS 10\% & ODS 30\% & Substrate \\
\hline Coating thickness & $344 \pm 8$ & $291 \pm 7$ & $257 \pm 12$ & $308 \pm 13$ & $5-7$ mm (no coating) \\
\hline
\end{tabular}

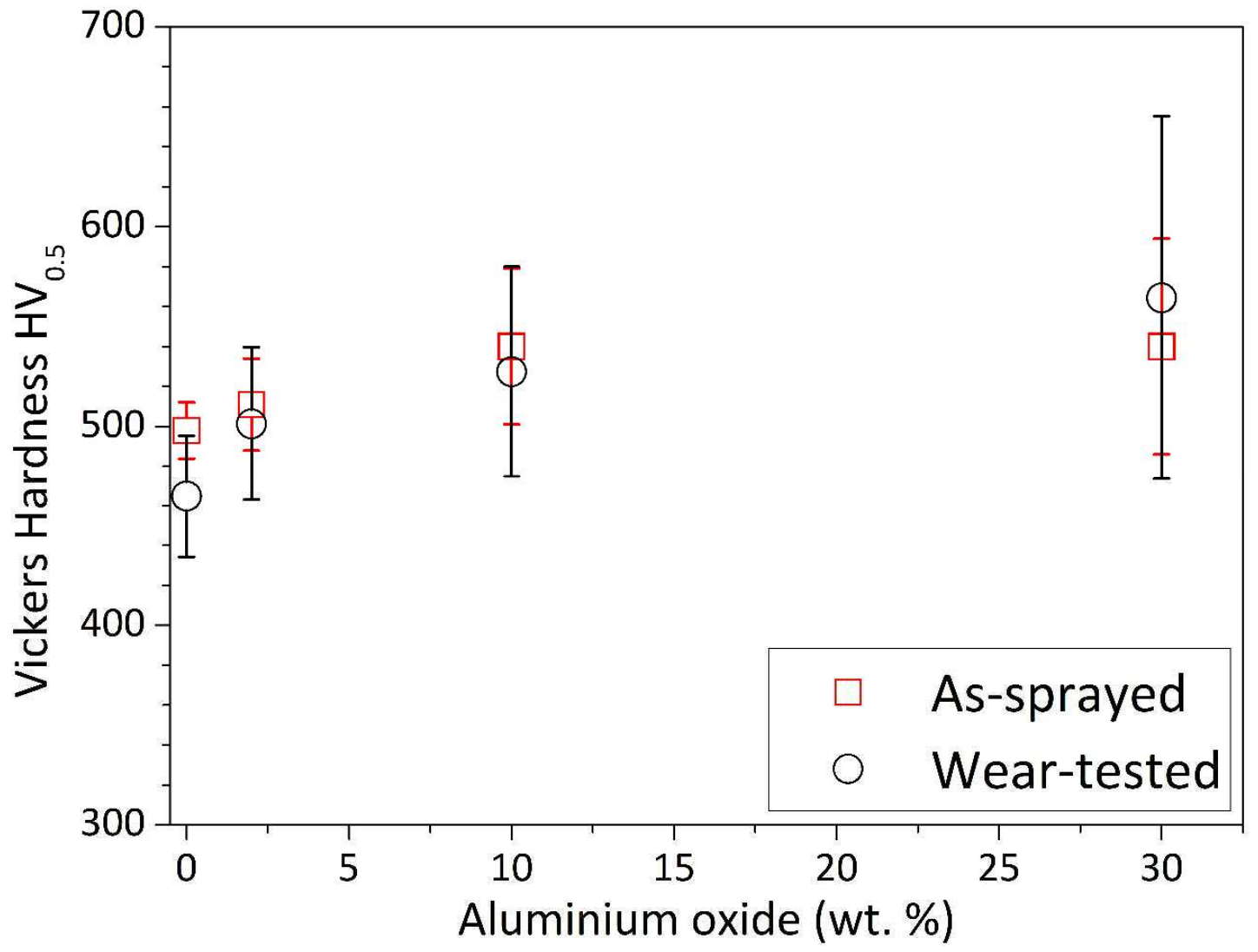

Figure 2. Vickers Hardness values of vacuum plasma sprayed oxide dispersion strengthened materials with different alumina additions measured in as-deposited condition and after isothermal exposure at $750{ }^{\circ} \mathrm{C}$ for $\approx 4 \mathrm{~h}$ during the ball-on-disc wear test.

The hardness of the coating material increases by a maximum of $8 \%$ through alumina addition (Figure 2). ODS materials with 10\% and 30\% alumina additions show comparable hardness values. Specifically, with high $\mathrm{Al}_{2} \mathrm{O}_{3}$ content, the as-deposited ODS coatings could suffer from 
some brittleness. Crack opening during indenter penetration would explain why hardness does not increase in the as-deposited 30\% ODS sample, and why its results are comparatively more scattered than in all other cases (Figure 2).

\subsection{Sliding wear behaviour at $750^{\circ} \mathrm{C}$}

Sliding wear rates decrease continuously when passing from the uncoated ERBO-1 substrate to MCrAlY coatings containing increasing amounts of $\mathrm{Al}_{2} \mathrm{O}_{3}$, with the notable exception of the $10 \%$ ODS sample, which, to the contrary, suffered the highest wear rate (Figure 3). Especially, the $30 \%$ ODS sample reveals a wear rate of $\approx 3 \times 10^{-6} \mathrm{~mm}^{3} /(\mathrm{N} \cdot \mathrm{m})$, one order of magnitude lower than that of the uncoated substrate $\left(\approx 3 \times 10^{-5} \mathrm{~mm}^{3} /(\mathrm{N} \cdot \mathrm{m})\right)$. The $30 \%$ ODS coating therefore appears particularly promising for high-temperature applications. For instance, its wear rate is within the typical range of $\mathrm{HVOF}$-sprayed $\mathrm{Cr}_{3} \mathrm{C}_{2}-\mathrm{NiCr}$ coatings tested at a slightly lower temperature of 700 ${ }^{\circ} \mathrm{C}\left(\approx 3-4 \times 10^{-6} \mathrm{~mm}^{3} /(\mathrm{N} \cdot \mathrm{m})[19,20]\right)$. Slightly higher wear rates of $\approx 5 \times 10^{-6} \mathrm{~mm}^{3} /(\mathrm{N} \cdot \mathrm{m})$ were obtained at $700{ }^{\circ} \mathrm{C}$ from similar $\mathrm{NiCrAlY}+\mathrm{Al}_{2} \mathrm{O}_{3}$ coatings with or without the addition of h-BN, produced by a "hybrid" plasma spray process whereby a dry NiCrAlY powder was co-injected together with suspensions of fine $\mathrm{Al}_{2} \mathrm{O}_{3}$ and hexagonal-BN powders [15]. A NiMoAl- $-\mathrm{Cr}_{2} \mathrm{O}_{3}-\mathrm{Ag}-$ $(\mathrm{Ca}, \mathrm{Ba}) \mathrm{F}_{2}$ plasma-sprayed coating (PS400) exhibited higher specific wear rates of approx. $1 \times 10^{-5}$ $\mathrm{mm}^{3} /(\mathrm{N} \cdot \mathrm{m})$ at a nearly identical temperature of $760{ }^{\circ} \mathrm{C}$ [8]. Sliding tests in the cited reference were, however, carried out under conditions that differ significantly from the present ones; therefore, results might not be fully comparable.

The average friction coefficient, on the other hand, increases continuously from $\approx 0.36$ for the uncoated substrate to $\approx 0.57$ for the $30 \%$ ODS sample (Figure 3 ). The latter value might not be well suited to dry sliding applications. Ball wear rates, though orders of magnitude lower than coating wear rates, are also higher when sliding against ODS samples than they are against 
uncoated ERBO-1 (Figure 3: note the different scales on the two distinct y-axes respectively showing coating and ball wear rates). Of all the coated samples, however, the $30 \%$ ODS one inflicts the lowest wear to the ball.

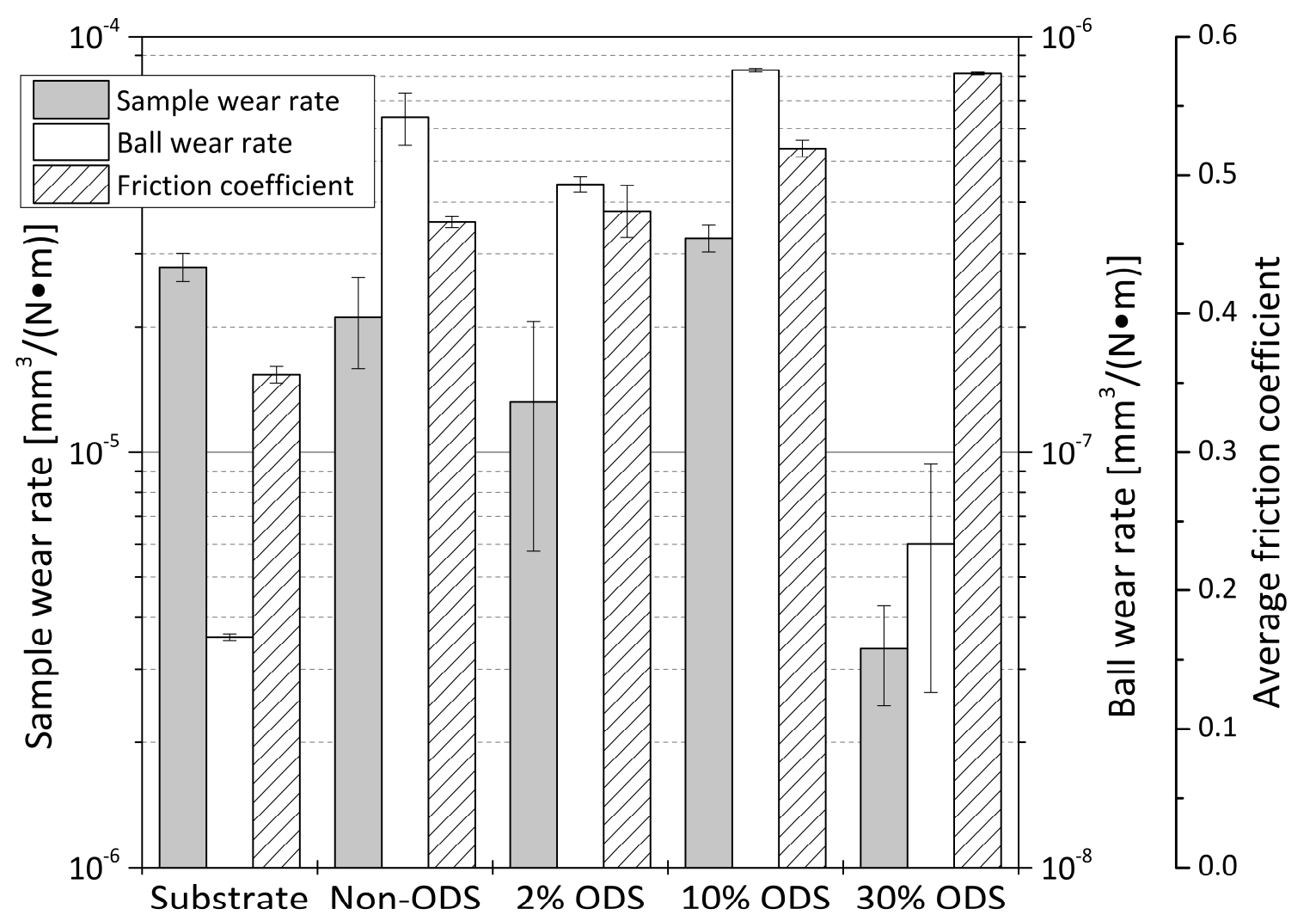

Figure 3. Quantitative results from ball-on-disc wear testing at $750{ }^{\circ} \mathrm{C}$ : wear rates of coatings and counterparts, and average friction coefficients.

An analysis of worn samples can clarify the different trends in sample and ball wear rates and friction coefficients. The uncoated substrate exhibits clear evidence of ductile abrasive grooving as its main wear mechanism (Figure 4A, B), whereas no adhesive tearing is seen even in a magnified view (Figure 4B). Asperities on the much harder $\mathrm{Al}_{2} \mathrm{O}_{3}$ counterpart can easily penetrate the comparatively soft metal surface at $750{ }^{\circ} \mathrm{C}$ and plough or, more probably, cut through it while encountering limited resistance. 


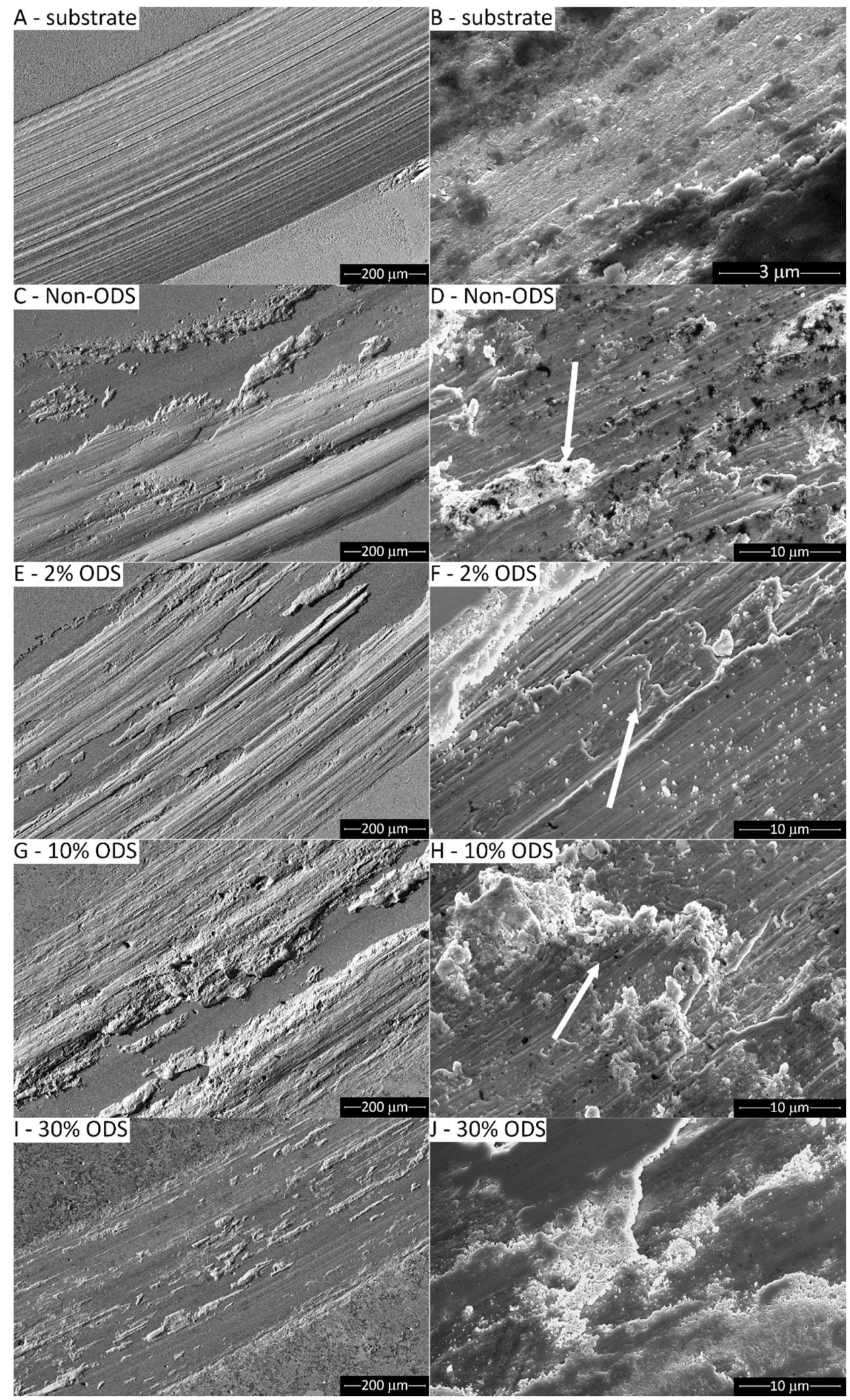

Figure 4. SEM micrographs of ball-on-disc wear scars produced at $750{ }^{\circ} \mathrm{C}$ on the substrate $(\mathrm{A}, \mathrm{B})$ and on samples Non-ODS (C, D), 2\% ODS (E, F), 10\% ODS (G, H), 30\% ODS (I,J). Arrows indicate evidence of plastic flow and adhesive tearing. 
This explains the high sample wear rate and low ball wear rate. The limited adhesive contribution to friction [21] also accounts for the comparatively low friction coefficient.

Cross-sectional views (Figure 5A, B) show that, as a consequence of abrasive grooving by the asperities on the counterpart, a plastically deformed region, $\approx 10 \mu \mathrm{m}$ deep, is developed (Figure 5A: white arrows). It can further be told into two areas: next to the surface, up to a depth of few micrometres, the typical $\gamma / \gamma^{\prime}$ texture of the superalloy (with $\gamma^{\prime}$ cubes within the brighter $\gamma$ matrix) is completely lost (Figure 5B: black arrow). Below this most severely deformed area, the $\gamma / \gamma^{\prime}$ microstructure is still recognizable, yet distorted.

The detailed views of Figure 4B, C also show the presence of dark patches of tribo-oxidized debris smeared onto the sample surface. By comparing the very broad Raman peaks of this debris to reference spectra from the RRUFF project database [22] (Figure 6), the presence of $\mathrm{NiO}$ and some $\mathrm{Cr}_{2} \mathrm{O}_{3}$ can be identified. The debris, therefore, consists primarily of tribo-oxidized constituents of the ERBO-1 alloy. The inset of Figure 6 shows the spectral region where the fluorescence emission of $\mathrm{Al}_{2} \mathrm{O}_{3}$ occurs: the presence of a distinguishable signal indicates the existence of alumina within the tribofilm. It is more likely that alumina originates from oxidation of $\mathrm{Al}$ contained in the metallic debris released by the worn alloy, rather than from inclusion of ball fragments. The volume loss of the alumina ball is, indeed, one order of magnitude lower than the coating loss.

The tribofilm onto the substrate seems to be particularly thin and, therefore, not much protective against abrasion from the counterpart (Figure 4A). Cross-sectional views (Figure 5A-C) indeed show that the tribofilm can barely fill in some of the abrasive grooves on the sample surface, while other parts are left entirely uncovered, hence unprotected. This results in the observed low wear resistance. 


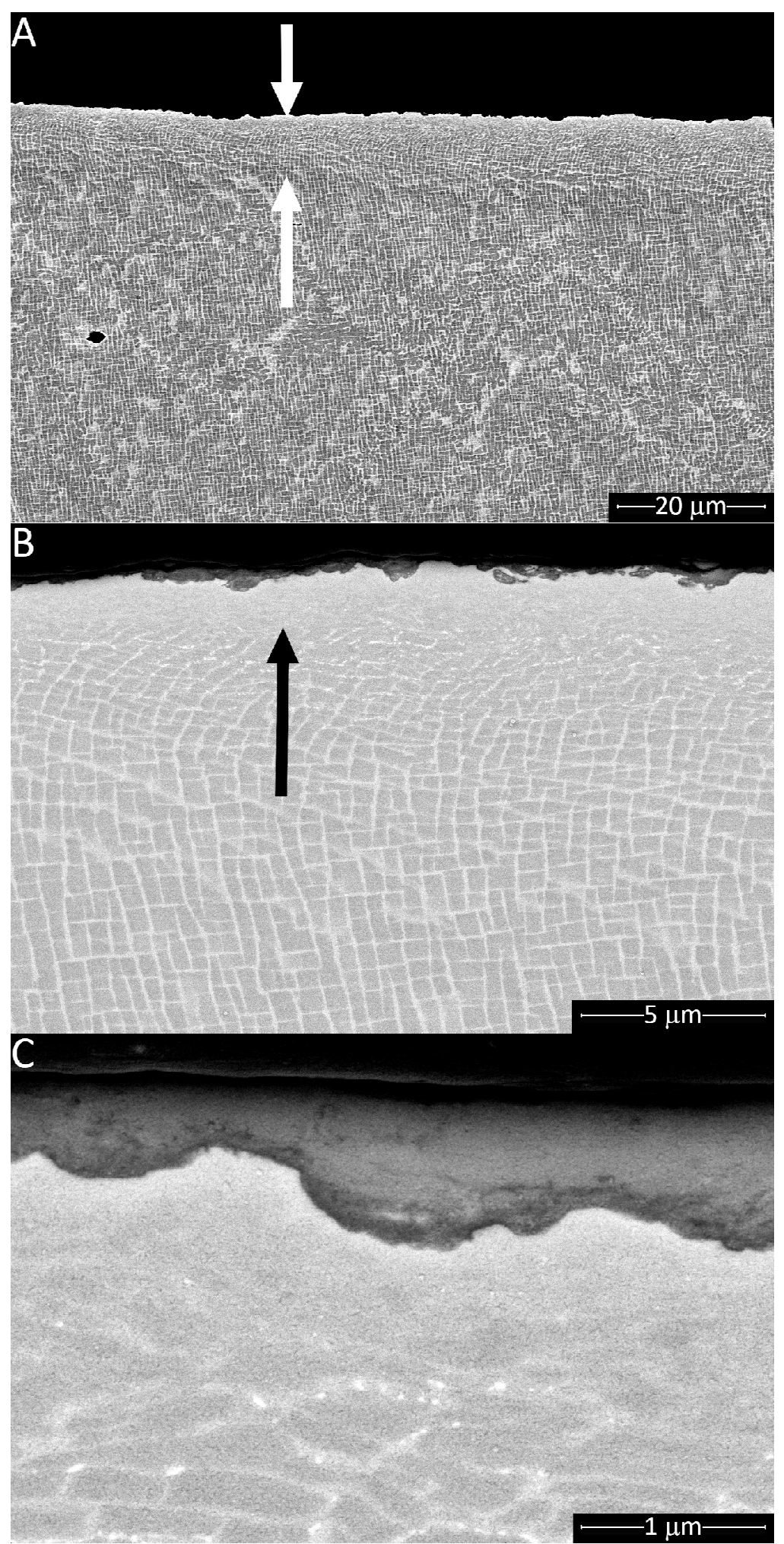

Figure 5. SEM micrographs of the polished cross-section of a ball-on-disc wear scar produced at $750{ }^{\circ} \mathrm{C}$ on the substrate: overview (A) and details at increasingly high magnification (B,C). Arrows indicate plastically deformed areas. 


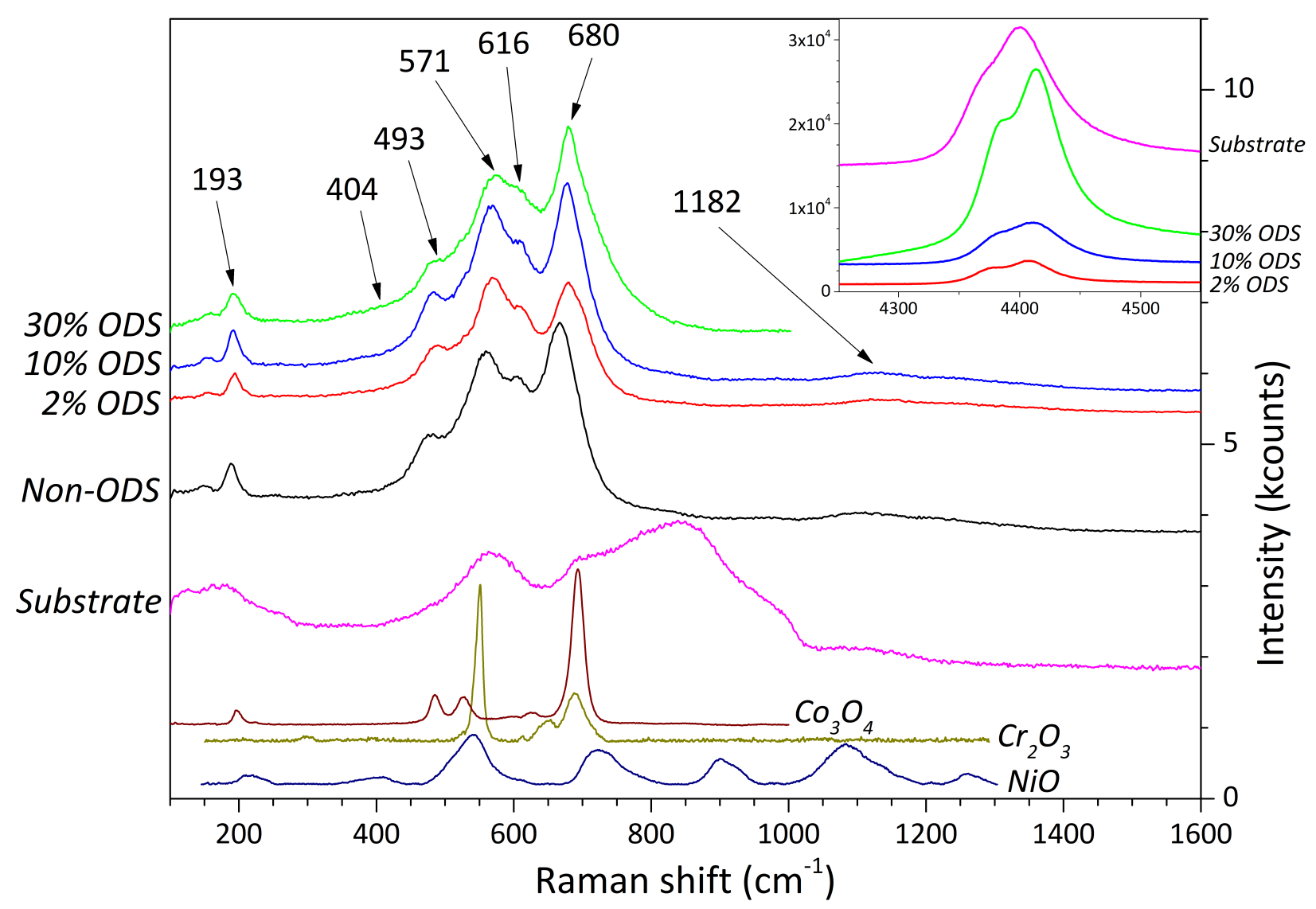

Figure 6. Micro-Raman spectra of the tribofilm layers formed on the substrate and the various

Non-ODS and ODS coatings after ball-on-disc testing at $750{ }^{\circ} \mathrm{C}$, compared to reference spectra of $\mathrm{NiO}, \mathrm{Cr}_{2} \mathrm{O}_{3}$ and $\mathrm{Co}_{3} \mathrm{O}_{4}$ taken from the RRUFF database [22]. The inset shows the fluorescence peak of $\mathrm{Al}_{2} \mathrm{O}_{3}$.

Adhesive/delaminative wear, rather than abrasive wear, seems to be the main degradation mechanism of coated samples. In fact, although scratches are visible on worn coating surfaces at low magnification (Figure 4C, E, G), magnified details reveal evidence of plastic shearing. It shows up in the form of quite distinctive "lips", consisting of material that has been plastically dragged in the direction of motion (Figure 4D, F, H: arrows). The accumulation of plastic strain eventually leads to failure, which appears in the form of fragmentation at the tips of those "lips". The damage accumulated through repeated plastic deformation causes the uplifting of platelets of coating material, as seen on cross-sections (Figure 7C, Figure 8B: circles). 


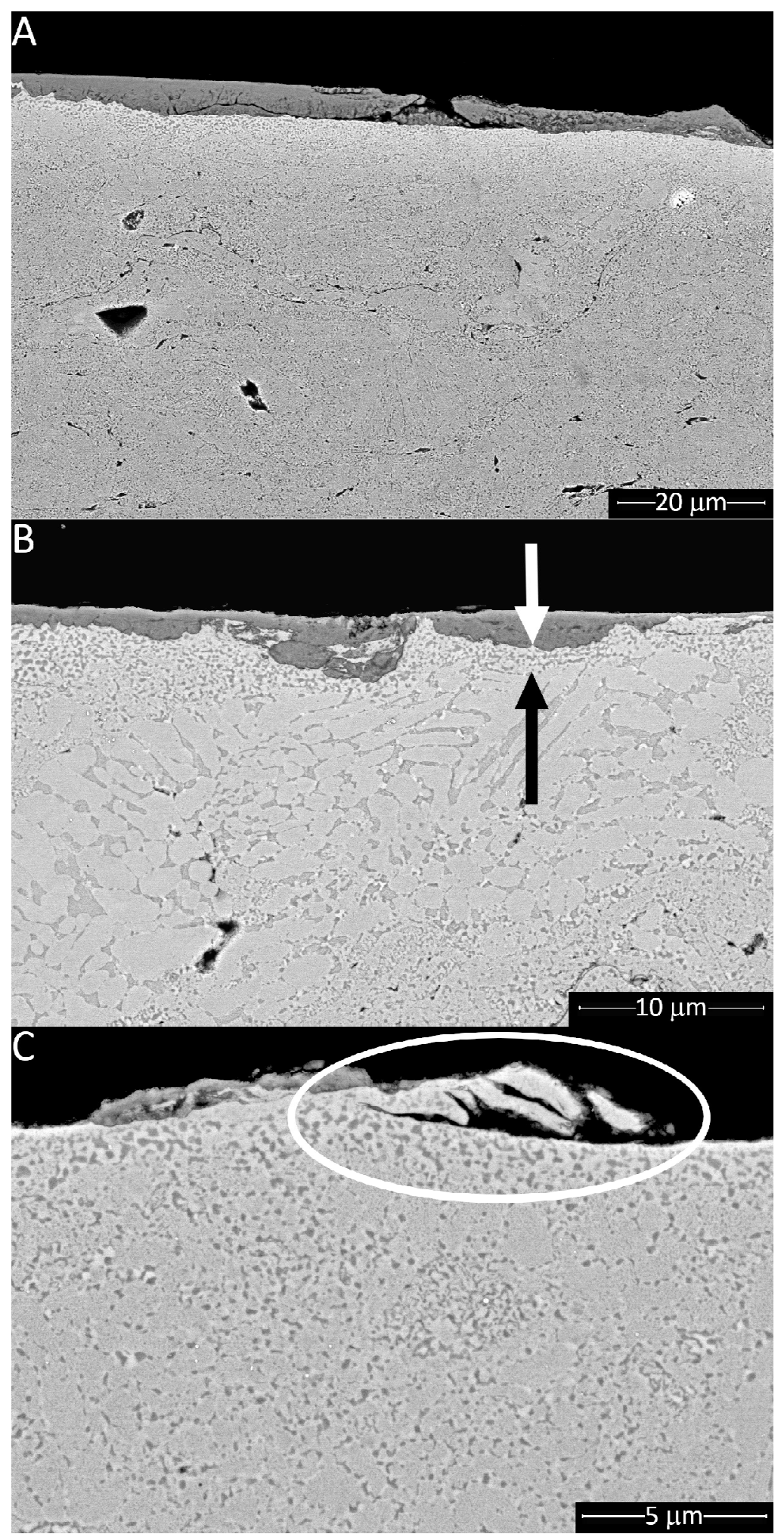

Figure 7. SEM micrographs of the polished cross-section of a ball-on-disc wear scar produced at $750{ }^{\circ} \mathrm{C}$ on the Non-ODS coating: overview (A) and details at increasingly high magnification $(B, C)$. Arrows in panel B indicate a re-crystallized area, the circle in panel C indicates the formation of a platelet-like debris by adhesive wear. 


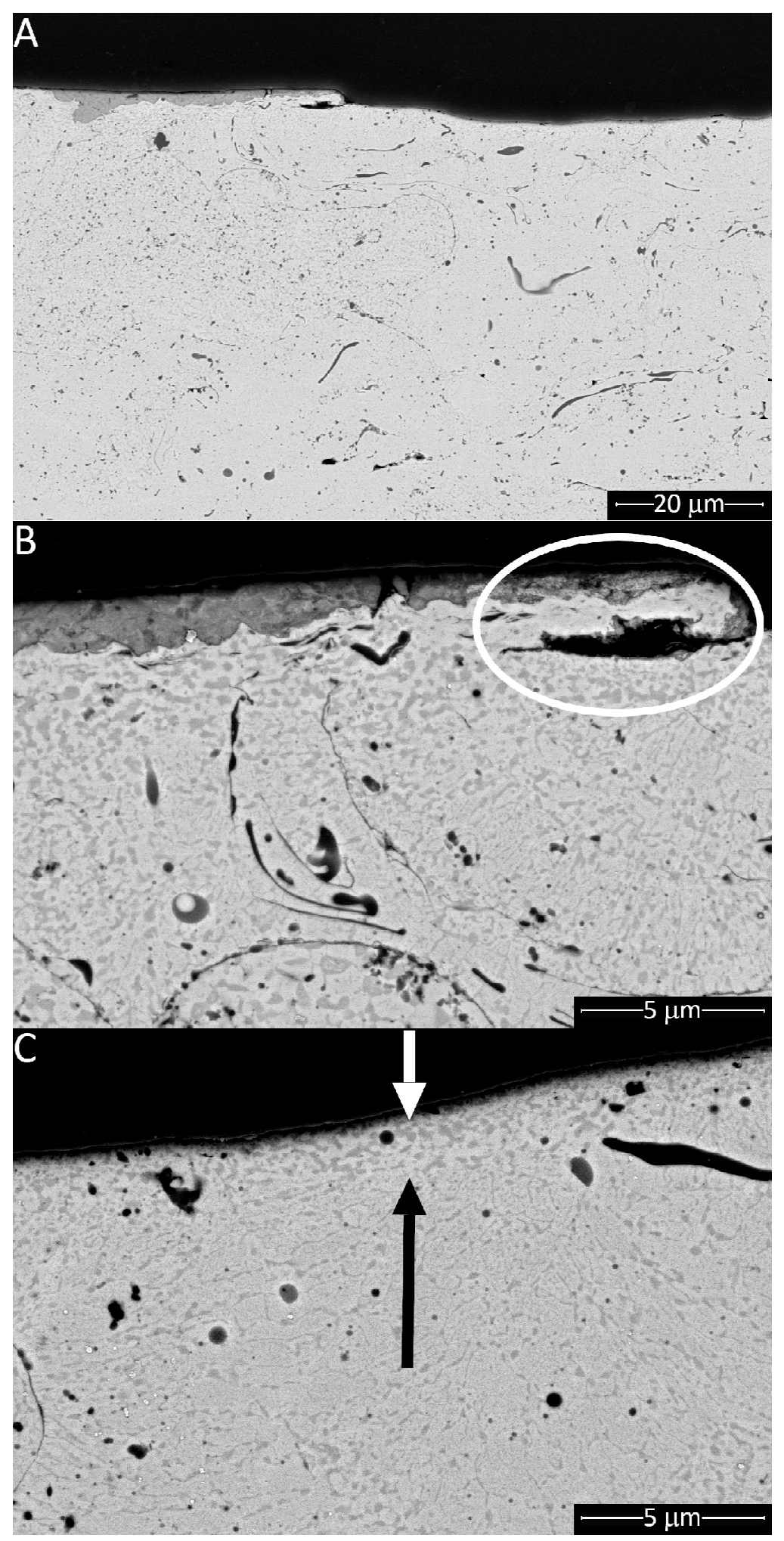

Figure 8. SEM micrographs of the polished cross-section of a ball-on-disc wear scar produced at $750{ }^{\circ} \mathrm{C}$ on the $2 \%$ ODS coating: overview (A) and details at increasingly high magnification $(B, C)$. Arrows in panel $C$ indicate a re-crystallized area, the circle in panel $B$ indicates the formation of a platelet-like debris by adhesive wear. 


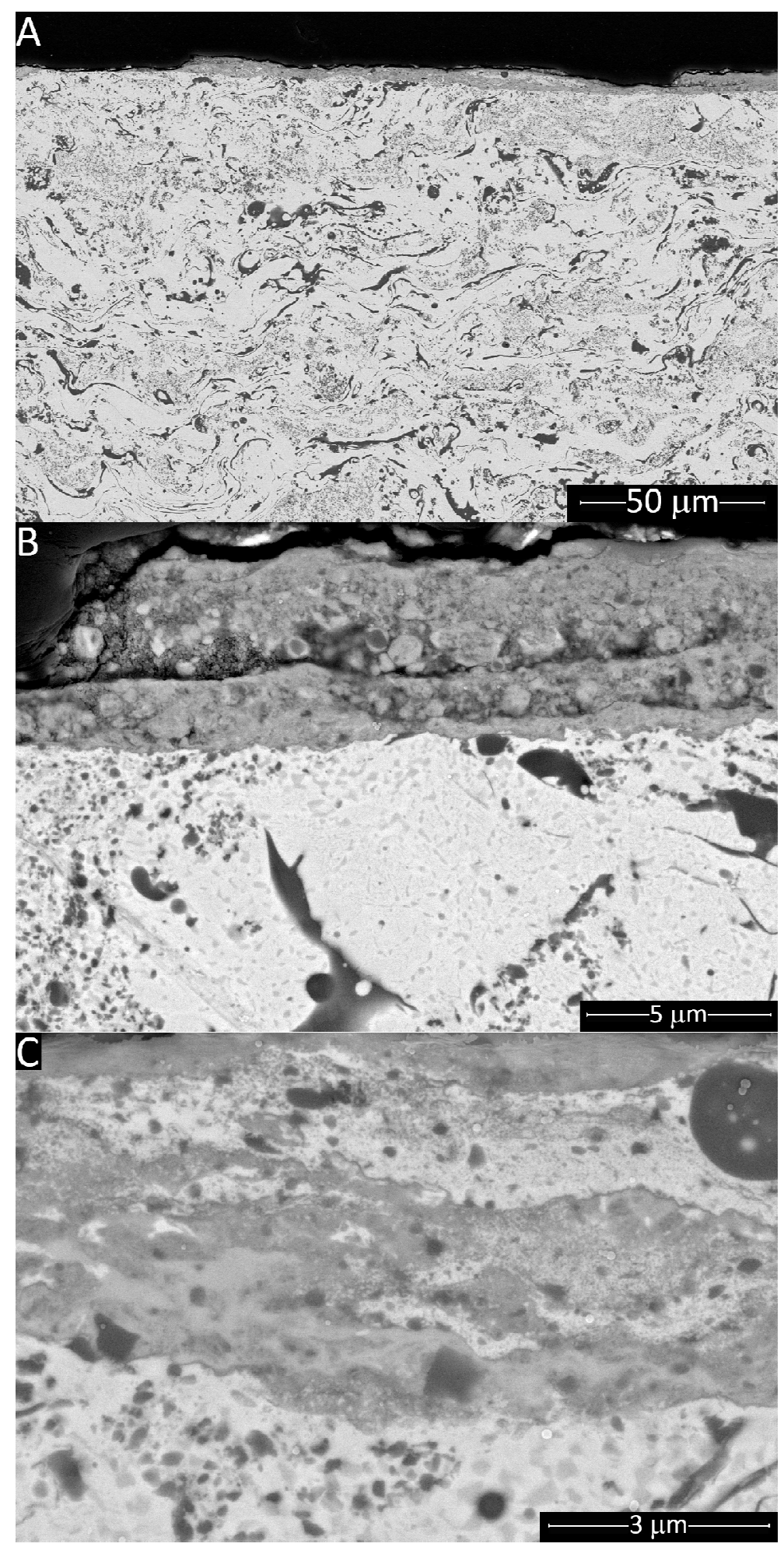

Figure 9. SEM micrographs of the polished cross-section of a ball-on-disc wear scar produced at $750{ }^{\circ} \mathrm{C}$ on the $10 \%$ ODS coating: overview (A) and details at increasingly high magnification $(\mathrm{B}, \mathrm{C})$. 


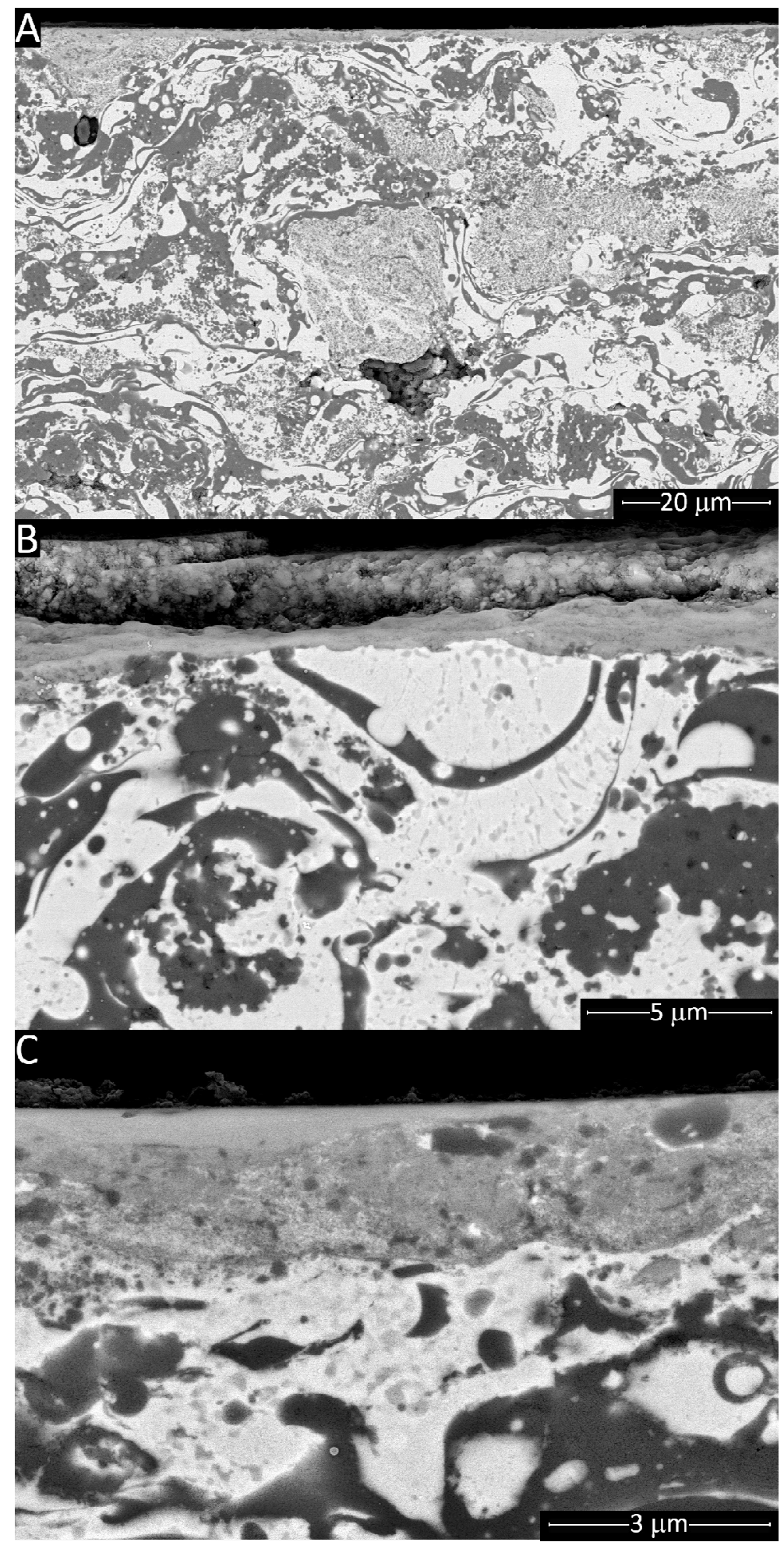

Figure 10. SEM micrographs of the polished cross-section of a ball-on-disc wear scar produced at $750{ }^{\circ} \mathrm{C}$ on the $30 \%$ ODS coating: overview (A) and details at increasingly high magnification $(\mathrm{B}, \mathrm{C})$. 
Lamellar fragments are eventually detached from the coating surface. If expelled from the contact area, they can be subsequently found in the loose debris at the end of the test (Figure 11A,B). The detail of the large fragment from the 10\% ODS sample in Figure 11B, in particular, shows visible $\mathrm{Al}_{2} \mathrm{O}_{3}$ particles, confirming that it is indeed a platelet of plastically deformed coating material. Apart from the large platelet, the debris in Figure 11A and C contains numerous, tiny fragments: based on EDX spectra, they mainly consist of oxides. This indicates the occurrence of tribooxidation; the fine size and rounded morphology of the fragments is indeed typical of such mechanism [21]. Specifically, fine oxidized fragments come from the comminution and oxidation of the larger platelets of coating material that are not expelled from the contact area.

At the same time, the worn coated surfaces are irregularly covered by an oxidized tribofilm (Figure 4C,E,G,I). On all coatings (cross-sectional views in Figure 7 - Figure 10), and especially on the 10 and $30 \mathrm{wt} \%$ ODS (Figure 9B-C, Figure 10B-C), the tribofilm is much thicker than it is on the uncoated substrate. Such very thick, oxidized tribofilm is also called a "glaze" layer in the pertinent literature [23-29]. Hence, the term "glaze" will be hereafter employed to differentiate it from the thinner and non-protective tribofilm previously described on the uncoated ERBO-1 substrate. The thick "glaze" plays a key role in limiting the wear loss of the coatings, which would otherwise be very severe, based on the extent of adhesive/delaminative damage seen in the uncovered areas. Because of the glaze, the wear resistance of the coated samples is higher than that of the substrate. One exeption is the $10 \%$ ODS sample, which will be discussed later in this section.

Figure 9B and Figure 10B show two examples of areas where the "glaze" has been fractured and is being reformed through the incipient compaction of the fine, oxidized fragments described previously. Loose oxidized fragments (Figure 11C) and particles in non-compacted portions of the "glaze" (Figure 11D) are, indeed, substantially identical. Consistent with the available 
literature [24,27], the "glaze" layer is therefore the result of smearing, compaction and sintering of tribo-oxidized debris produced during the wear process itself.

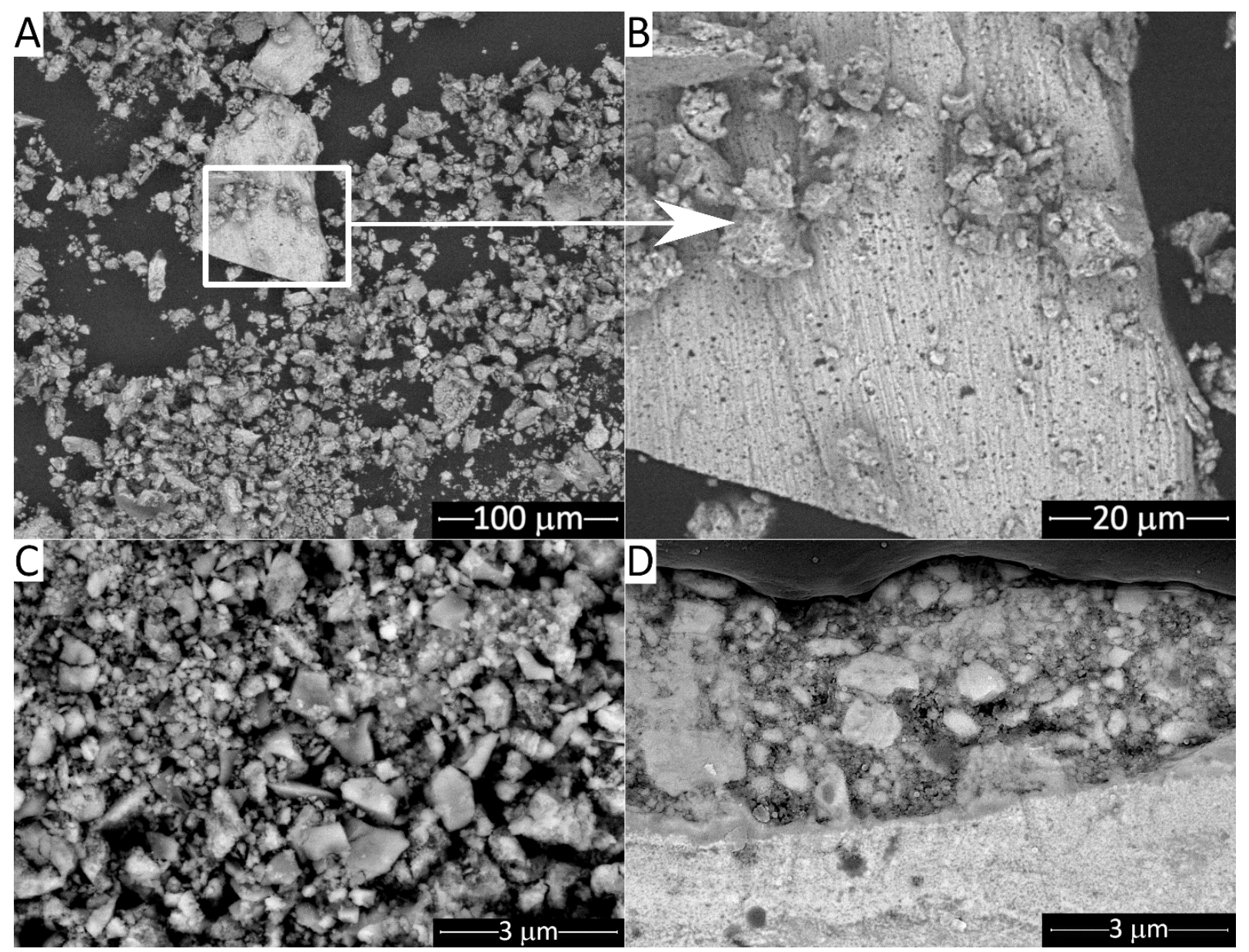

Figure 11. SEM micrographs of the wear debris produced by ball-on-disc sliding wear testing of sample $10 \%$ ODS (A,B) and Non-ODS (C) at $750{ }^{\circ} \mathrm{C}$, compared to non-sintered particles in the "glaze" layer (D: sample 2\% ODS).

The detail of Figure 12 specifically shows debris particles as they are being compacted into new "glaze". Particles are subjected to contact forces acting in the normal and tangential directions, as well as to contact temperatures that are presumably in excess of $750{ }^{\circ} \mathrm{C}$, due to the flash heating phenomenon [30]. When the compaction process is complete, individual particles become undistinguishable, as is visible especially in the magnified micrographs of Figure 9C and Figure 10C. Once the "glaze" is formed, however, it does not remain in a "static" condition during the 
wear test. It experiences a cyclic process of cracking, spallation, and reformation through the compaction of new debris particles, as evidenced by cross-sections (Figure 9B and Figure 10B, Figure 11D, Figure 12) and top-surface views (Figure 4J).

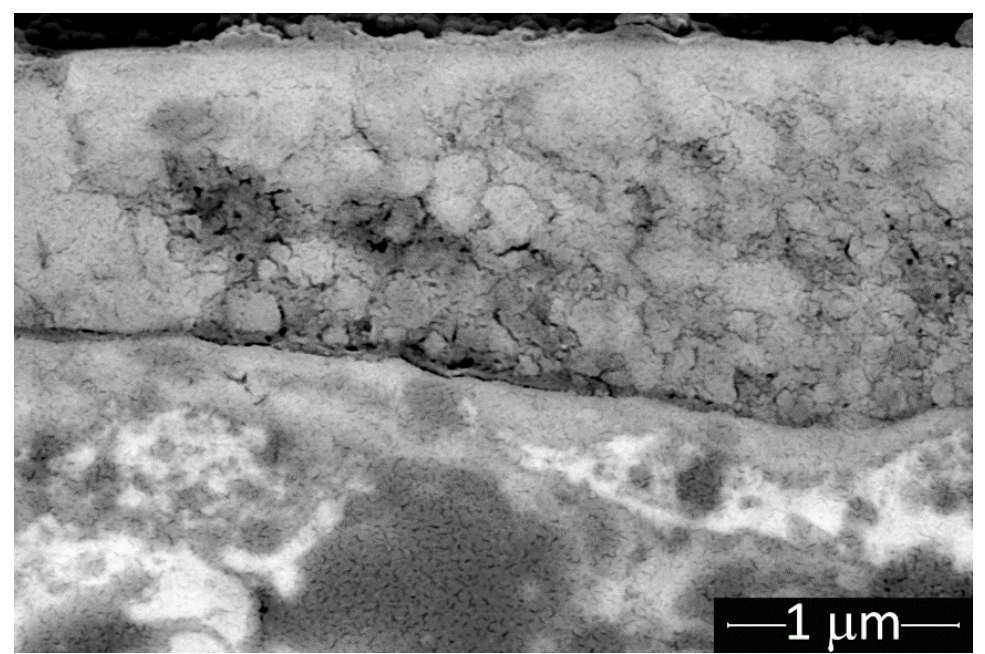

Figure 12. Detail of an almost fully sintered layer of debris particles in the "glaze" layer of sample $30 \%$ ODS.

The composition of the "glaze" on the coated samples is profoundly different from that of the thin and irregular tribofilm formed on the uncoated substrate (Figure 6). The Raman peaks of the "glaze" layer indeed match with the reference spectrum of $\mathrm{Co}_{3} \mathrm{O}_{4}$ (from the RRUFF database [22]) and with literature spectra of other Co-based spinel oxides, such as $\mathrm{CoAl}_{2} \mathrm{O}_{4}[31,32]$ and $\mathrm{CoCr}_{2} \mathrm{O}_{4}[31,33,34]$. As anticipated previously, the metallic debris fragments released by the coating alloy are fully oxidized, and such fully oxidized debris makes up the "glaze" by being smeared and compacted onto the worn surface.

The difference between the type of tribo-oxides found on the ERBO-1 substrate and the CoNiCrAlY matrix clearly follows from the specific compositions of the two alloys. It is probably the reason why tribo-oxidized fragments from the CoNiCrAlY-based coatings are able 
to build into a thick "glaze", unlike those from the substrate. Different alloys are indeed known to have much different ability to develop such "glazes" [23].

The inset in Figure 6 shows that the $\mathrm{Al}_{2} \mathrm{O}_{3}$ content in the "glaze" is closely linked to that in the coating. In particular, the "glaze" formed on the pure MCrAlY coating contains no $\mathrm{Al}_{2} \mathrm{O}_{3}$, suggesting that, as metallic aluminium in the MCrAlY debris reacts with oxygen, it enters the Cobased spinels previously detected by Raman spectroscopy (e.g. $\mathrm{CoAl}_{2} \mathrm{O}_{4}$ ). This is yet another difference between the tribo-oxidation behaviour of the coatings and the substrate, where Al formed a pure oxide phase instead. All of the alumina phase in the "glaze" originates from the release of reinforcing particles in the coating. It does not originate from the embedment of counterbody fragments, if not for an undetectably small amount. Compared to the coating, the wear loss of the counterbody is lower by more than one order of magnitude. The volume of debris coming from the counterbody is, therefore, more than 10 times lower than that coming from the coating.

Wear resistance of the coatings depends primarily on their ability to restrain "glaze" failure: the more the "glaze" tends to spall off, the more severe is the adhesive wear on the unprotected coating surface. $\mathrm{Al}_{2} \mathrm{O}_{3}$ in the coating can affect this behaviour in various, favourable or unfavourable ways:

1) The dispersion of $\mathrm{Al}_{2} \mathrm{O}_{3}$ particles enhances the strength/hardness of the MCrAlY coatings at high temperature. The coating therefore provides better mechanical support to the "glaze" and mitigates its tendency to spall, enhancing the wear resistance of the system. This is conceptually similar to the case of a harder substrate enhancing the adhesion of thin-film coatings (such as PVD nitride films), as reported in the literature [35].

Cross-sectional views of worn samples provide direct evidence to the different mechanical behaviour of unreinforced and reinforced CoNiCrAlY. Indeed, directly below the worn surface of 
MCrAlY coatings that contain little or no $\mathrm{Al}_{2} \mathrm{O}_{3}$, a thin layer exists, where the $\beta$-NiAl phase is restructured into a fine, equiaxed morphology (Figure 7B and Figure 8C: arrows; detail in Figure 13: arrows). This can be interpreted as re-crystallization of a plastically deformed region developed through the adhesive/delaminative wear phenomena described previously.

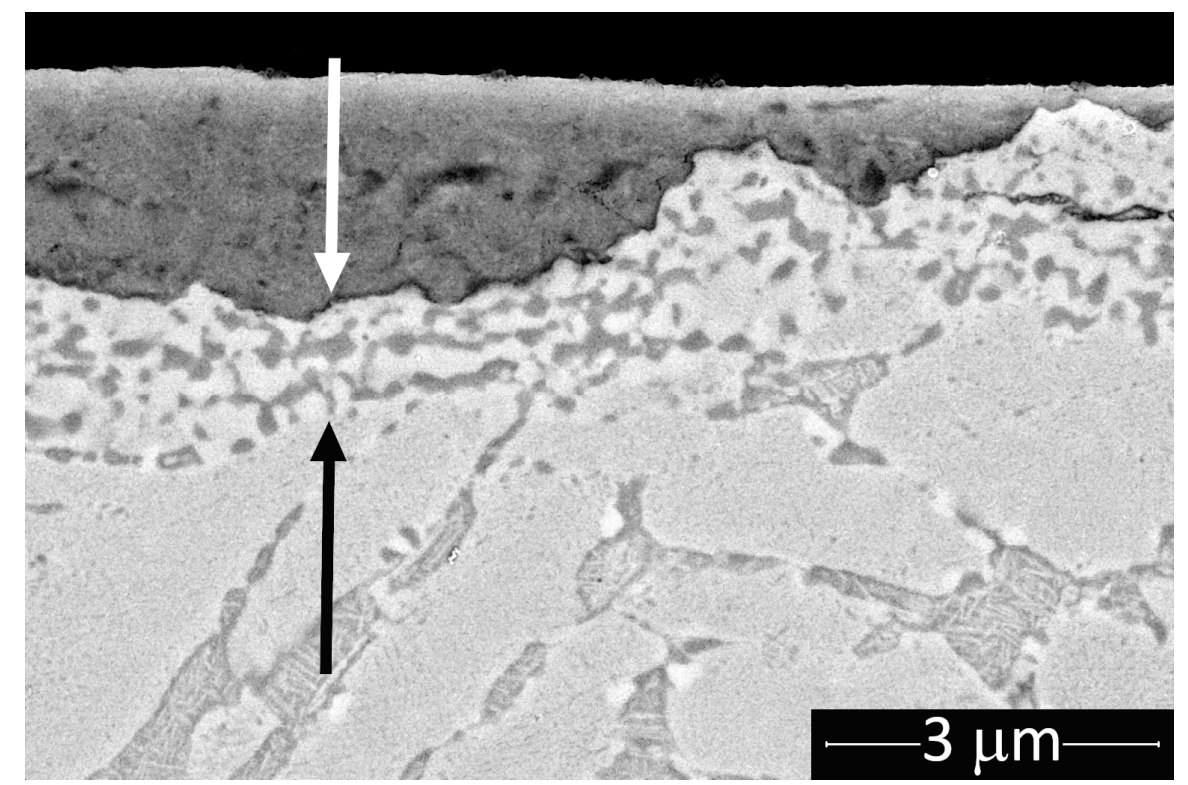

Figure 13. SEM micrograph showing a detail of the cross-section of the wear scar on sample "Non-ODS". Arrows show a recrystallized "skin" layer directly beneath the worn surface.

The tendency of the MCrAlY alloy towards re-crystallization is witnessed by the fact that, even outside the wear track, the amount of $\beta$-NiAl phase increased relative to that of the $\gamma / \gamma^{\prime}$ phase after the sample was kept at $750{ }^{\circ} \mathrm{C}$ during the wear test (see XRD patterns in Figure 14). The $\beta$ NiAl phase, which was partly lost by the melt-quenching phenomenon in plasma-sprayed splats, was indeed restored as the alloy recovered its thermodynamic equilibrium structure at $750{ }^{\circ} \mathrm{C}$. Likewise, it is reasonable to expect that, each time a plastic shearing event occurs on the metal surface at $750{ }^{\circ} \mathrm{C}$, the altered crystalline structure readily undergoes recovery and recrystallization. The CoNiCrAlY surface, therefore, is not expected to work-harden appreciably 
during high-temperature sliding, and continues to experience renewed adhesive/delaminative wear whenever it is left uncovered.
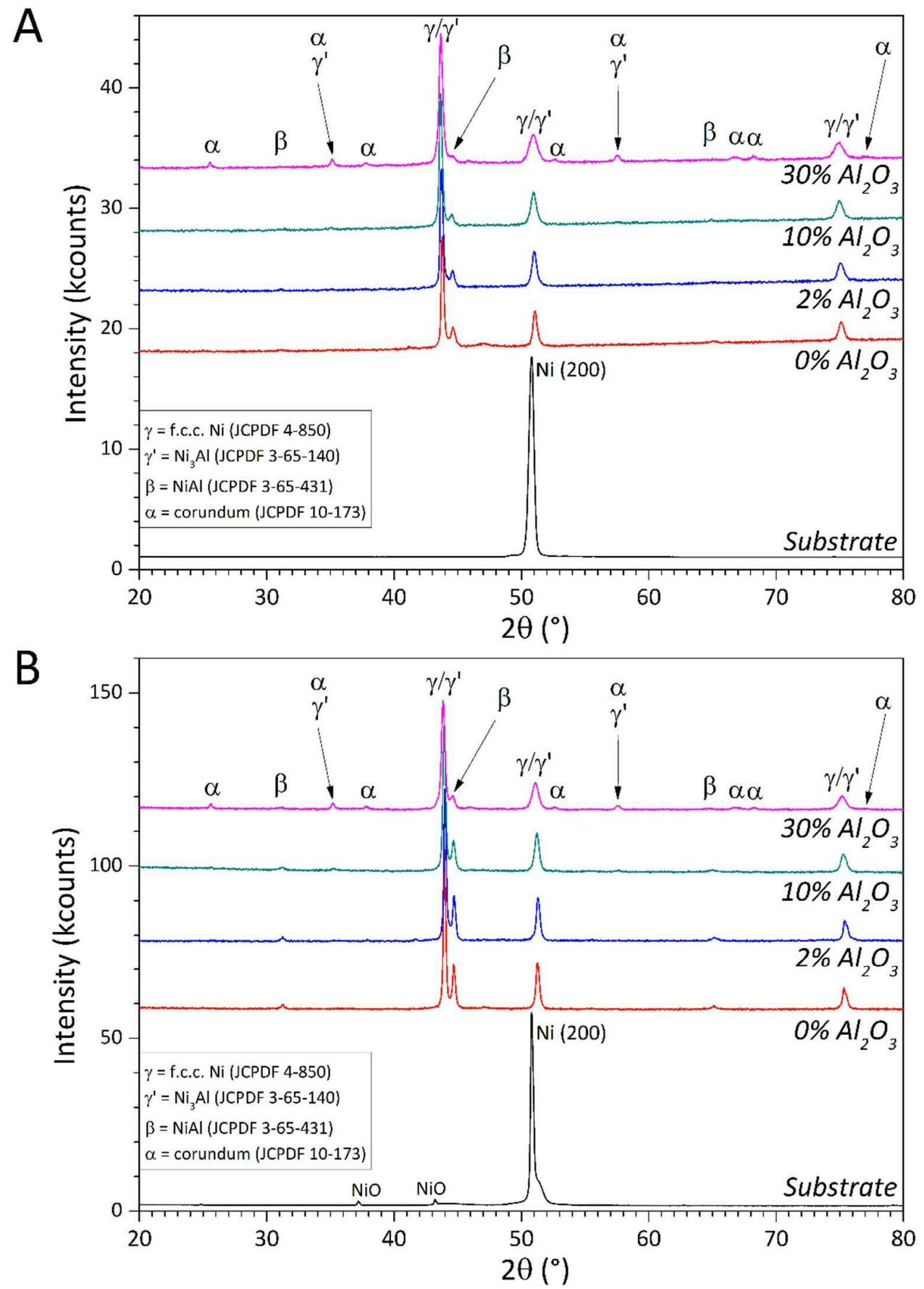

Figure 14. XRD patterns acquired on the substrate and the coatings before (A) and after (B) ballon-disc testing at $750{ }^{\circ} \mathrm{C}$. Patterns on wear-tested samples were acquired outside the wear scar. 
This fact stresses the importance of the "glaze" in order to restrain an otherwise very severe wear of the metallic alloy. It also means the non-reinforced MCrAlY coating surface never develops enough hardness to support a "glaze" film.

In the $30 \%$ ODS sample (Figure 10B,C), by contrast, the re-crystallized "skin" is not visible, because the numerous $\mathrm{Al}_{2} \mathrm{O}_{3}$ particles limit the plastic flow of the metal matrix. The whole system probably possesses higher hot hardness compared to all other ODS and non-ODS materials, thus providing better mechanical support to the "glaze". This can be easily understood by referring to the literature concerning the mechanical behaviour of conceptually similar systems comprising a hard PVD or CVD layer onto plastic substrates [35-37]. Experiments and finite element calculations have shown that, when a ductile surface (in the present case, the VPS coating) underneath a much harder layer (the oxide "glaze") starts deforming plastically, the surface layer is subjected to significant tensile stress peaks [36]. This leads to cracking and spallation of the layer. A harder underlying surface cooperates more effectively with the layer to carry the contact stresses, avoiding dangerous stress concentrations in the layer itself and at the interface [35,37].

It should be remarked that hardness measured at room temperature in as-deposited condition, as shown in Figure 2, is probably not representative of hot hardness. As noted in Section 3.1, the high content of $\mathrm{Al}_{2} \mathrm{O}_{3}$ in the $30 \%$ ODS material probably causes it to crack during indentation at room temperature. Brittleness, however, is most likely overcome at $750{ }^{\circ} \mathrm{C}$; indeed, there is no visible sub-surface crack in the cross-section of the worn 30\% ODS sample (Figure 10). High-temperature hardness measurements could not be carried out in this research to provide additional support to the above considerations. Hardness values measured at room temperature after wear testing are quite similar to those measured in as-deposited condition (Figure 2). Differences between average values might not be statistically significant as they are smaller than 
the associated error ranges. Nonetheless, those differences would suggest that hardness values at low $\mathrm{Al}_{2} \mathrm{O}_{3}$ content decrease very slightly after isothermal exposure at $750{ }^{\circ} \mathrm{C}$. This could follow from the recovery of the highly strained, supersaturated structure of the as-deposited samples, as discussed previously. The hardness of the $30 \%$ ODS sample, by contrast, would seem to increase slightly after exposure at $750{ }^{\circ} \mathrm{C}$, so that the overall trend of the wear-tested samples is that of a slight, continuous increase in hardness with increasing $\mathrm{Al}_{2} \mathrm{O}_{3}$ content. This might suggest a mitigation of brittleness. It is likely that brittleness is further mitigated when the material is at 750 ${ }^{\circ} \mathrm{C}$, and that the increase in hardness with increasing $\mathrm{Al}_{2} \mathrm{O}_{3}$ content is even more marked. 2) $\mathrm{Al}_{2} \mathrm{O}_{3}$ particles or fragments thereof can also be released from the coating during the wear process and are entrained in the "glaze" layer. This is seen in Figure 9C and Figure 10C and in the Raman spectra of Figure 6. They probably act as a reinforcement; hence, they favour wear resistance by enhancing the hardness of the glaze.

3) On the other hand, tribo-oxidized debris particles from the metal alloy (not $\mathrm{Al}_{2} \mathrm{O}_{3}$ fragments) are primarily responsible for the formation of the "glaze", and the latter probably adheres much better to the ductile MCrAlY surface than to hard and chemically inert $\mathrm{Al}_{2} \mathrm{O}_{3}$ particles. Therefore, breaking the continuity of the metal surface through the dispersion of $\mathrm{Al}_{2} \mathrm{O}_{3}$ particles might unfavourably impair its ability to develop a uniform "glaze", like it is visible for the $10 \%$-ODS material.

At every $\mathrm{Al}_{2} \mathrm{O}_{3}$ content, a balance is established between effects 1 (enhancing "glaze" stability by hardening the coating through alumina addition) and 2 (enhancing "glaze" hardness by alumina transport in the "glaze"), which are favourable to the formation of a stable, continuous "glaze", and effect 3 (alumina breaking the continuity of the "glaze"), which is instead detrimental. It is therefore inferable that $10 \% \mathrm{Al}_{2} \mathrm{O}_{3}$ content elicits an especially unfavourable combination, which 
indeed leads to a largely spalled "glaze" and severe adhesive wear of the unprotected metal surface (Figure 4G, H). To the contrary, $30 \% \mathrm{Al}_{2} \mathrm{O}_{3}$ content is particularly favourable, probably because the coating is strengthened enough to provide conspicuously improved mechanical support to the tribofilm. Moreover, in case the "glaze" is spalled, adhesive wear of the exposed metal surface is somewhat limited by the same strengthening phenomenon, as testified by the previously noted absence of a clear re-crystallized "skin" under the worn surface of this sample.

\section{Conclusions}

This paper aimed to characterize the high-temperature sliding wear resistance of aluminium oxide-dispersion strengthened (ODS) CoNiCrAlY coatings obtained by vacuum plasma spraying of ball milled powders, compared to a pure CoNiCrAlY coating and to an uncoated ERBO-1 (CMSX-4) superalloy.

It is found that the pure CoNiCrAlY coating is subject to severe adhesive/delaminative wear by plastic shearing. Plastically deformed areas near the worn surface are seen to re-crystallize at 750 ${ }^{\circ} \mathrm{C}$, which also suggests that the material cannot work-harden during sliding, leaving it vulnerable to further adhesive wear. Nonetheless, the sliding wear rate of the pure CoNiCrAlY coating is lower than that of the uncoated ERBO-1 superalloy substrate. Key to such result is the formation of a thick $(>1 \mu \mathrm{m})$ "glaze" layer via compaction and (probable) sintering of tribo-oxidized debris particles onto the wear scar of the CoNiCrAlY coating. The "glaze" layer reduces the damage due to adhesive wear by limiting the surface area in direct contact with the $\mathrm{Al}_{2} \mathrm{O}_{3}$ counterbody. The ERBO-1 substrate is incapable of forming a comparable "glaze" and, even though it does not experience as much adhesive wear, it suffers from continuous abrasive wear from the counterbody. 
The "glaze" developed onto the CoNiCrAlY coating experiences dynamic conditions of spallation and re-formation during sliding. Limited "glaze" spallation is therefore essential for improved wear resistance. A fine dispersion of $\mathrm{Al}_{2} \mathrm{O}_{3}$ particles can have multiple effects that are either favourable or unfavourable to this end.

Specifically:

- $\mathrm{Al}_{2} \mathrm{O}_{3}$ particles can enter the "glaze" layer and enhance its strength;

- Although hot hardness was not measured, evidence from the surfaces and cross-section of the worn samples suggests that $\mathrm{Al}_{2} \mathrm{O}_{3}$ particles increase the hot hardness of the coating. Therefore, it provides better mechanical support to the "glaze" layer, avoiding stress concentrations that are probably the main reason of its periodic spallation;

- $\mathrm{Al}_{2} \mathrm{O}_{3}$ particles can break the continuity of the metallic surface to which the "glaze" can attach, thus favouring spallation of the latter during sliding. This effect clearly goes contrary to the previous one.

Based on the balance among these phenomena, the wear resistance of ODS CoNiCrAlY coatings does not vary linearly with $\mathrm{Al}_{2} \mathrm{O}_{3}$ content. There can be $\mathrm{Al}_{2} \mathrm{O}_{3}$ contents that lead to unfavourable balances, resulting in increased wear. For example, in the present system, an addition of $10 \mathrm{wt} \%$ $\mathrm{Al}_{2} \mathrm{O}_{3}$ did cause severe impairment of the wear resistance because of frequent and extensive spallation of the "glaze" during sliding. The $10 \% \mathrm{Al}_{2} \mathrm{O}_{3}$-containing ODS coating experiences higher sliding wear rate than both the unreinforced CoNiCrAlY and the uncoated superalloy. With the addition of 2 wt. $\% \mathrm{Al}_{2} \mathrm{O}_{3}$, moderate improvement over the wear resistance of unreinforced CoNiCrAlY is instead observed, whilst a conspicuous enhancement is achieved with 30 wt. $\% \mathrm{Al}_{2} \mathrm{O}_{3}$. The absence of any sub-surface plastic flow (and subsequent recrystallization) and, at the same time, of any sub-surface crack means that the coating has high hot hardness and good toughness, so that it provides good support to the "glaze". The latter thus 
covers most of the worn surface; moreover, the reinforced coating resists adhesive wear in the infrequent case the "glaze" spalls off.

On the downside, the ODS coatings produced higher friction coefficient than the uncoated superalloy under the present test conditions. This means a possible future development of this work might encompass the addition of high-temperature solid lubricants to the formulation.

\section{Funding sources}

This research did not receive any specific grant from funding agencies in the public, commercial, or not-for-profit sectors. 


\section{References}

[1] S. Tin, T.M. Pollock, Nickel-Based Superalloys, in: T.I.-P. Shih, V. Yang (Eds.), Turbine Aerodyn. Heat Transf. Mater. Mech., American Institute of Aeronautics and Astronautics, Inc., Reston, VA, 2014: pp. 423-466. doi:10.2514/5.9781624102660.0423.0466.

[2] T.M. Pollock, S. Tin, Nickel-Based Superalloys for Advanced Turbine Engines: Chemistry, Microstructure and Properties, J. Propuls. Power. 22 (2006) 361-374. doi:10.2514/1.18239.

[3] S. Bose, High Temperature Coatings, Elsevier, Oxford, UK, 2018. doi:10.1016/C2015-001316-8.

[4] M.R. Dorfman, D. Sporer, P. Meyer, Thermal Spray Technology Growth in Gas Turbine Applications, in: R.C. Tucker Jr. (Ed.), ASM Handb. - Vol. 5A Therm. Spray Technol., ASM International, Materals Park, OH, USA, 2013: pp. 280-286.

doi:10.31399/asm.hb.v05a.a0005737.

[5] T.N. Rhys-Jones, Coatings for blade and vane applications in gas turbines, Corros. Sci. 29 (1989) 623-646. doi:10.1016/0010-938X(89)90104-2.

[6] F. Cernuschi, C. Guardamagna, S. Capelli, L. Lorenzoni, D.E. Mack, A. Moscatelli, Solid particle erosion of standard and advanced thermal barrier coatings, Wear. 348-349 (2016) 43-51. doi:10.1016/j.wear.2015.10.021.

[7] D. Lubell, C. DellaCorte, M. Stanford, Test Evolution and Oil-Free Engine Experience of a High Temperature Foil Air Bearing Coating, in: Vol. 5 Mar. Microturbines Small Turbomachinery; Oil Gas Appl. Struct. Dyn. Parts A B, ASME, 2006: pp. 1245-1249. doi:10.1115/GT2006-90572.

[8] K. Radil, C. DellaCorte, The Performance of PS400 Subjected to Sliding Contact at Temperatures from 260 to $927^{\circ} \mathrm{C}$, Tribol. Trans. 60 (2017) 957-964. 
doi:10.1080/10402004.2016.1231357.

[9] C. Vorkötter, D.E. Mack, O. Guillon, R. Vaßen, Superior cyclic life of thermal barrier coatings with advanced bond coats on single-crystal superalloys, Surf. Coatings Technol. 361 (2019) 150-158. doi:10.1016/j.surfcoat.2019.01.001.

[10] T. Huang, J. Bergholz, G. Mauer, R. Vassen, D. Naumenko, W.J. Quadakkers, Effect of test atmosphere composition on high-temperature oxidation behaviour of CoNiCrAlY coatings produced from conventional and ODS powders, Mater. High Temp. 35 (2018) 97-107. doi:10.1080/09603409.2017.1389422.

[11] C. Vorkötter, S.P. Hagen, G. Pintsuk, D.E. Mack, S. Virtanen, O. Guillon, R. Vaßen, Oxide Dispersion Strengthened Bond Coats with Higher Alumina Content: Oxidation Resistance and Influence on Thermal Barrier Coating Lifetime, Oxid. Met. 92 (2019) 167194. doi:10.1007/s11085-019-09931-z.

[12] J. Bergholz, B.A. Pint, K.A. Unocic, R. Vaßen, Fabrication of Oxide Dispersion Strengthened Bond Coats with Low $\mathrm{Al}_{2} \mathrm{O}_{3}$ Content, J. Therm. Spray Technol. 26 (2017) 868-879. doi:10.1007/s11666-017-0550-9.

[13] K. Bobzin, T. Schläfer, K. Rlchardt, M. Brühl, High temperature behavior of newly developed oxide dispersion strengthened NiCoCrAlY coatings, in: B.R. Marple, M.M. Hyland, Y.-C. Lau, C.-J. Li, R.S. Lima, G. Montavon (Eds.), Expand. Therm. Spray Perform. to New Mark. Appl. Proc. Int. Therm. Spray Conf., ASM International, Materials Park, OH, USA, 2009: pp. 1030-1035. doi:10.1361/cp2009itsc1030.

[14] G. Bolelli, A. Candeli, L. Lusvarghi, A. Ravaux, K. Cazes, A. Denoirjean, S. Valette, C. Chazelas, E. Meillot, L. Bianchi, Tribology of $\mathrm{NiCrAlY}+\mathrm{Al}_{2} \mathrm{O}_{3}$ composite coatings by plasma spraying with hybrid feeding of dry powder+suspension, Wear. 344-345 (2015) 69-85. doi:10.1016/j.wear.2015.10.014. 
[15] G. Bolelli, A. Candeli, L. Lusvarghi, T. Manfredini, A. Denoirjean, S. Valette, A. Ravaux, E. Meillot, "Hybrid" plasma spraying of NiCrAlY+Al2O3+h-BN composite coatings for sliding wear applications, Wear. 378-379 (2017) 68-81. doi:10.1016/j.wear.2017.02.027.

[16] Oerlikon Metco - Thermal Spray Materials Guide, (2017). https://www.oerlikon.com/ecomaXL/files/oerlikon_BRO0001.17_TS_MaterialGuide_EN.pdf (accessed June 15, 2019).

[17] M. Watson, M. Marshall, Wear mechanisms at the blade tip seal interface, Wear. 404-405 (2018) 176-193. doi:10.1016/j.wear.2018.03.009.

[18] P. Sassatelli, G. Bolelli, L. Lusvarghi, T. Manfredini, R. Rigon, Manufacturing and Properties of High-Velocity Oxygen Fuel (HVOF)-Sprayed FeVCrC Coatings, J. Therm. Spray Technol. 25 (2016) 1302-1321. doi:10.1007/s11666-016-0451-3.

[19] G. Bolelli, B. Bonferroni, J. Laurila, L. Lusvarghi, A. Milanti, K. Niemi, P. Vuoristo, Micromechanical properties and sliding wear behaviour of HVOF-sprayed Fe-based alloy coatings, Wear. 276-277 (2012) 29-47. doi:10.1016/j.wear.2011.12.001.

[20] V. Matikainen, G. Bolelli, H. Koivuluoto, P. Sassatelli, L. Lusvarghi, P. Vuoristo, Sliding wear behaviour of HVOF and HVAF sprayed $\mathrm{Cr}_{3} \mathrm{C}_{2}$-based coatings, Wear. 388-389 (2017) 57-71. doi:10.1016/j.wear.2017.04.001.

[21] G. Straffelini, Friction and Wear, Springer International Publishing, Cham, 2015. doi:10.1007/978-3-319-05894-8.

[22] B. Lafuente, R.T. Downs, H. Yang, N. Stone, The power of databases: The RRUFF project, in: T. Armbruster, R.M. Danisi (Eds.), Highlights Mineral. Crystallogr., De Gruyter, Berlin, München, Boston, 2015: pp. 1-30. doi:10.1515/9783110417104-003.

[23] F.H. Stott, D.S. Lin, G.C. Wood, The structure and mechanism of formation of the 'glaze' oxide layers produced on nickel-based alloys during wear at high temperatures, Corros. 
Sci. 13 (1973) 449-469. doi:10.1016/0010-938X(73)90030-9.

[24] P.D. Wood, H.E. Evans, C.B. Ponton, Investigation Into the Wear Films Formed on Certain Superalloys Between 20 and $600^{\circ} \mathrm{C}$ During Rotation in an Unlubricated Bearing, in: ASME/STLE 2009 Int. Jt. Tribol. Conf., ASME, Memphis, Tennessee, USA, 2009: pp. 91-93. doi:10.1115/IJTC2009-15162.

[25] I.A. Inman, P.K. Datta, H.L. Du, J.S. Burnell-Gray, S. Pierzgalski, Q. Luo, Studies of high temperature sliding wear of metallic dissimilar interfaces, Tribol. Int. 38 (2005) 812-823. doi:10.1016/j.triboint.2005.02.007.

[26] I.A. Inman, S.R. Rose, P.K. Datta, Development of a simple 'temperature versus sliding speed' wear map for the sliding wear behaviour of dissimilar metallic interfaces, Wear. 260 (2006) 919-932. doi:10.1016/j.wear.2005.06.008.

[27] P.D. Wood, H.E. Evans, C.B. Ponton, Investigation into the wear behaviour of Stellite 6 during rotation as an unlubricated bearing at $600^{\circ} \mathrm{C}$, Tribol. Int. 44 (2011) 1589-1597. doi:10.1016/j.triboint.2011.02.011.

[28] J. Jiang, F.H. Stott, M.M. Stack, A generic model for dry sliding wear of metals at elevated temperatures, Wear. 256 (2004) 973-985. doi:10.1016/j.wear.2003.09.005.

[29] P.J. Blau, Elevated-temperature tribology of metallic materials, Tribol. Int. 43 (2010) 1203-1208. doi:10.1016/j.triboint.2010.01.003.

[30] M.F. Ashby, J. Abulawi, H.S. Kong, Temperature Maps for Frictional Heating in Dry Sliding, Tribol. Trans. 34 (1991) 577-587. doi:10.1080/10402009108982074.

[31] H. Shirai, Y. Morioka, I. Nakagawa, Infrared and Raman Spectra and Lattice Vibrations of Some Oxide Spinels, J. Phys. Soc. Japan. 51 (1982) 592-597. doi:10.1143/JPSJ.51.592.

[32] B. Jongsomjit, J. Panpranot, J.G. Goodwin, Co-Support Compound Formation in AluminaSupported Cobalt Catalysts, J. Catal. 204 (2001) 98-109. doi:10.1006/jcat.2001.3387. 
[33] H.D. Lutz, B. Müller, H.J. Steiner, Lattice vibration spectra. LIX. Single crystal infrared and Raman studies of spinel type oxides, J. Solid State Chem. 90 (1991) 54-60. doi:10.1016/0022-4596(91)90171-D.

[34] M. Mączka, M. Ptak, M. Kurnatowska, J. Hanuza, M. Mączka, M. Ptak, M. Kurnatowska, J. Hanuza, Synthesis, phonon and optical properties of nanosized $\mathrm{CoCr}_{2} \mathrm{O}_{4}$, Mater. Chem. Phys. 138 (2013) 682-688. doi:10.1016/j.matchemphys.2012.12.039.

[35] C.T. Wang, T.J. Hakala, A. Laukkanen, H. Ronkainen, K. Holmberg, N. Gao, R.J.K. Wood, T.G. Langdon, An investigation into the effect of substrate on the load-bearing capacity of thin hard coatings, J. Mater. Sci. 51 (2016) 4390-4398. doi:10.1007/s10853016-9751-8.

[36] K. Holmberg, A. Laukkanen, H. Ronkainen, K. Wallin, S. Varjus, A model for stresses, crack generation and fracture toughness calculation in scratched TiN-coated steel surfaces, Wear. 254 (2003) 278-291. doi:10.1016/S0043-1648(02)00297-1.

[37] K. Holmberg, A. Laukkanen, H. Ronkainen, K. Wallin, S. Varjus, J. Koskinen, Tribological contact analysis of a rigid ball sliding on a hard coated surface: Part II: Material deformations, influence of coating thickness and Young's modulus, Surf. Coatings Technol. 200 (2006) 3810-3823. doi:10.1016/J.SURFCOAT.2005.03.041. 